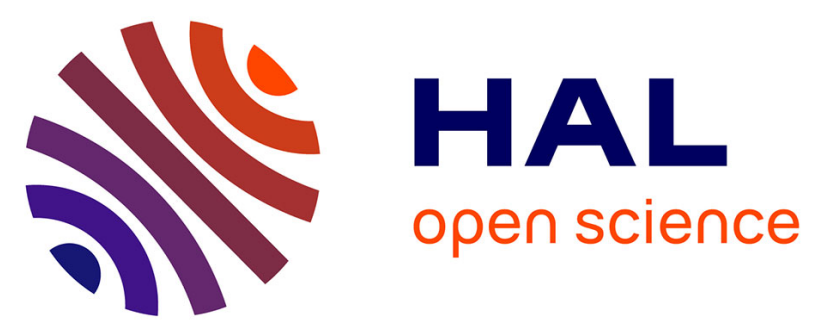

\title{
Contamination of soils by metals and organic micropollutants: case study of the Parisian conurbation
}

Johnny Gasperi, Sophie Ayrault, Elodie Moreau-Guigon, Fabrice Alliot, Pierre

Labadie, Hélène Budzinski, Martine Blanchard, Bogdan Muresan, Emilie

Caupos, Mathieu Cladière, et al.

\section{To cite this version:}

Johnny Gasperi, Sophie Ayrault, Elodie Moreau-Guigon, Fabrice Alliot, Pierre Labadie, et al.. Contamination of soils by metals and organic micropollutants: case study of the Parisian conurbation. Environmental Science and Pollution Research, 2018, 25 (24), pp.23559-23573. 10.1007/s11356-0168005-2 . hal-01396132

\section{HAL Id: hal-01396132 \\ https://hal-enpc.archives-ouvertes.fr/hal-01396132}

Submitted on 23 May 2018

HAL is a multi-disciplinary open access archive for the deposit and dissemination of scientific research documents, whether they are published or not. The documents may come from teaching and research institutions in France or abroad, or from public or private research centers.
L'archive ouverte pluridisciplinaire HAL, est destinée au dépôt et à la diffusion de documents scientifiques de niveau recherche, publiés ou non, émanant des établissements d'enseignement et de recherche français ou étrangers, des laboratoires publics ou privés. 


\title{
CONTAMINATION OF SOILS BY METALS AND ORGANIC MICROPOLLUTANTS: CASE STUDY OF THE PARISIAN CONURBATION
}

Johnny Gaspéri $^{1} *$, Sophie Ayrault ${ }^{2}$, Elodie Moreau-Guigon ${ }^{3}$, Fabrice Alliot $^{3}$, Pierre Labadie ${ }^{4}$, Hélène Budzinski ${ }^{4}$, Martine Blanchard ${ }^{3}$, Bogdan Muresan ${ }^{1}$, Emilie Caupos ${ }^{1}$, Mathieu Cladière $^{1}$, David Gateuille ${ }^{1}$, Bruno Tassin ${ }^{1}$, Louise Bordier ${ }^{2}$, Marie-Jeanne Teil ${ }^{3}$, Catherine Bourges $^{3}$, Annie Desportes ${ }^{3}$, Marc Chevreuil ${ }^{3}$, Régis Moilleron ${ }^{1}$

1. LEESU, Université Paris-Est, UMR-MA102, 61 av du Général de Gaulle, 94010 Créteil.

2. Laboratoire des Sciences du Climat et de l'Environnement, LSCE/IPSL, CEA-CNRS-UVSQ, Université Paris-Saclay, F-91198 Gif-sur-Yvette, France.

3. UMR METIS 7619, PSL Research University, Sorbonne Universités, 4 place Jussieu, 75005 Paris.

4. UMR 5805 EPOC, Equipe LPTC, Université de Bordeaux, 351 crs de la Libération, 33405 Talence.

* Corresponding author: gasperi@u-pec.fr

\begin{abstract}
Soils are playing a central role in the transfer and accumulation of anthropogenic pollutants in urbanized regions. Hence, this study aimed at examining the contamination levels of selected soils collected within and around the Paris conurbation (France). This also evaluated factors controlling contamination. Twenty-three trace and major elements as well as 82 organic micropollutants including polycyclic aromatic hydrocarbons (PAHs), polychlorinated biphenyls (PCBs), phthalates (PAEs), polybrominated diphenyl ethers (PBDEs), alkylphenols (APs) and perfluoroalkylated substances (PFASs) were analyzed. Results reinforced the concern raised by the occurrence and levels of metals such as $\mathrm{Zn}, \mathrm{Pb}, \mathrm{Cu}$ and $\mathrm{Hg}$, identified as metallic markers of anthropogenic activities but also pointed out the ubiquitous contamination of soils by organic micropollutants in the $0.2-55,000 \mu \mathrm{g} / \mathrm{kg} . \mathrm{dw}$ range. For well documented compounds like PAHs, PCBs and to a lesser extent PBDEs, contents were in the range of background levels worldwide. The pollutant stock in tested soil was compared to the annual atmospheric input. For PAHs, $\mathrm{Pb}$ and to a lesser extent $\mathrm{Zn}, \mathrm{Cu}, \mathrm{Cd}, \mathrm{Hg}, \mathrm{Sb}, \mathrm{PAEs}$ and $\mathrm{APs}$ a
\end{abstract}


significant stock was observed, far more important than the recent annual atmospheric fluxes. This resulted from both i) the persistence of a fraction of pollutants in surface soils and ii) the cumulative atmospheric inputs over several decades. Regarding PBDEs and PFASs, stronger atmospheric input contributions were observed thereby highlighting their recent dispersal into the environment.

\section{Keywords}

Metals, organic micropollutants, soils, black carbon, PAHs, PCBs, perfluoroalkylated substances

\section{Introduction}

Soils play an important role in metal and persistent organic pollutants (POPs) transfer and budget in a river basin because they behave as pollutant reservoirs and different processes occurring in soils influence the pollutant adsorption, retention, accumulation, dissipation and finally transfer to rivers (Meijer et al. 2003b). Soil contamination depends on the anthropogenic drivers, which are mainly associated to human land use and activities (agriculture, industrialization, river basin network activities and others) as well as the natural drivers (erosion, geochemical background, etc.).

Different databases on soil monitoring coupling or not metals with organic pollutants are available worldwide. Among these databases, the Swiss Soil Monitoring Network (NABO: Nationale Bodenboebachtung) investigated 8 historical metals ( $\mathrm{Cd}, \mathrm{Zn}, \mathrm{Pb}, \mathrm{Cu}, \mathrm{Hg}$, $\mathrm{Ni}, \mathrm{Cr}$, and $\mathrm{Co}$ ) and some organic micropollutants such as polycyclic aromatic hydrocarbons (PAHs), polychlorinated biphenyls (PCBs) and polychlorinated dibenzo-p-dioxins and -furans (PCDD/F) (Bucheli et al. 2004, Desaules et al. 2010). The national baseline survey of soil quality in the Netherlands investigates a larger broad of metals, as well as volatile organics, chlorinated volatile organics, PAHs and some pesticides (Brus et al. 2009). For this database, the vast majority of the observations were below the limit of quantification (LOQ). As an 
indication, for a little more than half of the 252 compounds, more than $95 \%$ of the observations were below the LOQ, implying that the estimated 95-percentile was smaller than the LOQ. In France, the French National Soil Monitoring Network (RMQS: Réseau de Mesures de la Qualité des Soils) measured PAHs, PCBs, PCDD/Fs and 26 herbicides (Villanneau et al. 2011). Most of these available databases, as also mainly observed in the literature, focused on a limited set of metals and well-known organic pollutants such as PAHs, PCBs and PCDD/Fs but other pollutants persistent and/or of emerging concern have been less considered. Besides, Sb is considered as a global emerging metal (Krachler et al. 2005, Le Cloarec et al. 2011) and is identified as an urbanization marker (Le Pape et al. 2012). Despite those evidences and the large reviews of trace and major elements in urban soils (Le Cloarec et al. 2011,), there are very scarce data on Sb and Ag occurrence in urban soils. For organic pollutants, data about perfluoroalkylated substances (PFASs), phthalates (PAEs), and to a lesser extent on polybrominated diphenyl ethers (PBDEs) and alkylphenols (APs) are extremely limited. Considering that i) a number of these pollutants have been both emitted in the atmospheric compartment and measured in atmospheric deposition for decades and ii) soil contamination may be mainly related to the cumulative atmospheric inputs, the first purpose of this study, carried out under the frame of the PIREN-Seine program devoted to the Seine River basin (France) was to contribute to available data in the scientific literature for these groups of pollutants. Hence, 105 micropollutants including metals, major elements and priority and emerging organic pollutants were monitored on 32 soils of the Parisian conurbation, including rural and densely urbanized sites. Furthermore, the soil parameters that may affect the contaminant sequestration in soil were investigated. Indeed, relationships between the soil organic matter (SOM) and the pollutants were investigated since SOM plays an important role in the pollutant partitioning and fate (Cornelissen et al. 1997). As black carbon (BC) is a component of SOM and is recognized as a "super sorbent" (Brandli et al. 
2008, Cornelissen \& Gustafsson 2005), relationships between PAHs, PCBs, PCDD/Fs and BC were also investigated (Nam et al. 2008, Villanneau et al. 2011, Wang et al. 2014). To date, correlations for other groups of pollutants such as PAEs, PFASs and APs have never been investigated. The last objectives of this paper were to assess the soil contamination in relation with land use (urban vs. rural soils) and finally, to evaluate the pollutant stocks in soil surface compared to recent atmospheric inputs. To date, atmospheric inputs are generally considered to assess the global pollutant budget at the scale of basin catchment (e.g., (Thevenot et al. 2007)) but their contribution to stocks in soils has never been investigated, to our knowledge, for such a large range of legacy and emerging contaminants.

\section{Materials and methods}

\subsection{Site description and sampling strategy}

In this research, 32 soil samples were tested for their mineral and organic pollutant contents (Figure 1). The tested soils were taken from a larger soil sample bank consisting of 120 soils sampled in 2009-2010 across the Greater Paris (France). The Greater Paris, hereafter referred as the Ile de France Region, is the shelter of about 12 million inhabitants while it represents less than $2 \%$ of the French territory (about 12,000 $\mathrm{km}^{2}$ ) (Meybeck et al. 2007). In this area, the Seine River with its tributaries drains a basin exposed to the chronic emissions of countless human activities including: the heavy road traffic, fuel facilities, industrial and domestic heating, factories, waste incineration plants, etc. At the scale of the Seine Basin, soil erosion was estimated to between 5 and $10 \mathrm{t} / \mathrm{km}^{2} /$ year (Meybeck et al. 2007). The sampling locations for tested soils are given as a supplementary material (Table S1). In order to cover different land uses, both rural $(n=12)$ and densely urbanized $(n=20)$ soils were collected. They were sampled in 2009-2010, using an auger to collect the first 10-cm layer. The auger mouth was pre-soaked for 12 hours in a 3\% TFD4 detergent solution, thoroughly rinsed with deionized water and then with HPLC-grade dichloromethane. Acetone on a clean tissue was 
used to carry out a rapid on-site cleaning. In order to minimize local heterogeneity and improve data representativeness, each surface soil samples were prepared by pooling three different cores collected $5 \mathrm{~m}$ from one another. Furthermore, to reduce cross contamination, every first core of each series was systematically discarded. The remaining samples were then homogenized, double-bagged in polyethylene bags (organic pollutants were preliminary wrapped in aluminum foil) and immediately placed in dark conditions in a cooler with frozen gel packs. Upon return to laboratory, the samples were then freeze-dried, ground, and kept in cold storage $\left(4^{\circ} \mathrm{C}\right)$ in plastic (for metals) and glass (for organic pollutants) bottles until analysis.

\subsection{Pollutant contents and soil parameters determination}

For each sample, total organic carbon (TOC) and black carbon (BC) were analyzed. TOC was analyzed after mineralization $(\mathrm{HCl} \mathrm{3 \% )}$ using an elemental analyzer (Shimadzu TOC-Vws). The BC content was determined with the chemothermal oxidation method (CTO375) based on previous published method (Gustafsson et al. 2001).

The full list of compounds analyzed is given in Table 1. A total of 105 individual substances were monitored. These consisted of 23 mineral substances (trace and major elements) and 82 organic pollutants. This category comprised 15 PAHs, 19 PCBs, 8 PBDEs, 7 PAEs, 7 nonylphenol and octylphenol polyethoxylates (NPnEOs and OPnEOs,), 22 PFASs as well as 4 individual compounds: bisphenol A (BPA), tetrabromobisphenol A (TBBPA), hexachlorobenzene (HCB) and pentachlorobenzene (PeCB). The usual abbreviation of each compound is also provided in Table 1.

For each group of compounds, some indicators were selected such as nonylphenols (NP) for APs, diethylhexyl phthalate (DEHP) for PAEs, fluoranthene for PAHs and BDE 209 for PBDEs. For PAHs, results were also expressed as $\sum 15 \mathrm{PAHs}$ or $\sum 6 \mathrm{PAHs}$ (fluoranthene, benzo(b)fluoranthene, benzo(k)fluoranthene, benzo(a)pyrene, indeno(cd)pyrene, 
benzo(ghi)perylene) according to French standard on air quality (NF X 43-025). For PCBs, $\sum 19 \mathrm{PCBs}$ or $\sum 7 \mathrm{PCBs}$ (PCB 28, 52, 101, 118, 138, 153 and 180) which are commonly observed in environment, are given. The $\sum 8 \mathrm{PCBs}$ « dioxin-like » $\mathrm{PCB}$ contents $(\mathrm{PCB} 28,33$, $70,77,105,118,105$ and 170) are also provided. For APs, the sum of 7 congeners ( $\sum 7 \mathrm{Aps}$, nonylphenols (NP), nonylphenol monoethoxylate (NP1EO), nonylphenol diethoxylate (NP2EO), octylphenol (OP), octylphenol monoethoxylate (OP1EO), octylphenol diethoxylate (OP2EO), nonylphenoxy acetic acid (NP1EC)) is given.

All pollutants were analyzed according to validated methods and analytical details for each group of compounds can be found in the mentioned reference. Most of the metals were analyzed by inductively coupled plasma mass spectrometry (ICP-MS, (Le Pape et al. 2014)). Total mercury $(\mathrm{Hg})$ in soils was analyzed using an automatic mercury analyzer (AMA 254 from Courtage Analyses, (Harris-Hellal et al. 2011)). PAHs and PAEs (Alliot et al. 2014) as well as PBDEs (Muresan et al. 2010) were analyzed by using gas chromatography coupled to mass spectrometry (GC-MS) and PCBs by GC coupled to tandem mass spectrometry (GCMS/MS; (Goutte et al. 2013)). Bisphenol A and APs (Cladiere et al. 2013) and PFASs (Munoz et al. 2015a) were analyzed by liquid chromatography coupled to tandem mass spectrometry (LC-MS/MS). The limits of quantification (LOQ) for each individual substance are provided in supplementary material - Table $\mathrm{S} 2$.

\section{Results and discussion}

\subsection{Contamination of soils}

$\underline{\text { Total organic carbon and black carbon }}$

The TOC contents in the tested Parisian soils varied between 0.54 and $9.14 \%$, with a mean value of $3.08 \pm 2.15 \%$ (mean \pm standard deviation $(\mathrm{SD})$ ). These values were lying typically in the middle or the upper range of commonly reported values worldwide for urban and rural soils. Besides, for British and Norwegian soils, Nam et al. (2008) found TOC 
contents in 5.4-46\% ranges. A mean TOC content of $1.34 \pm 0.54 \%$ was shown by Wang et al. (2014b) for urban and sub-urban soils close to Shanghai (China). In the present study, the BC contents in soil samples varied between 0.05 and $3.07 \%$ (mean value of $0.70 \pm 0.93 \%$ ). These values were in the same order of magnitude than values reported for soils in the UK and in Norway, i.e., from 0.24 to $1.80 \%$ with a mean value at $0.88 \%$ (Nam et al. 2008). Similarly, in the US, BC contents around $0.25 \%$ for urban soils and around $0.14 \%$ for agricultural soils (Hamilton \& Hartnett 2013) were reported. However, our results were higher than those reported by Wang et al. (2014) for soils, independently to the method used $(0.19 \pm 0.08 \%$ using CTO-375 method and $0.47 \pm 0.25 \%$ using $\mathrm{Cr}_{2} \mathrm{O}_{7}$ oxidation).

As previously demonstrated in literature, the $\mathrm{BC} / \mathrm{TOC}$ ratio can be used to get insight into the carbon origin, i.e. distinguishing between the burning of biomass and that of fossil fuels. $\mathrm{BC} / \mathrm{TOC}$ ratio method was based specific $\mathrm{BC} / \mathrm{TOC}$ ratio measured in aerosol during combustion of fuel or biomass (Gatari \& Boman 2003). In soil samples considered here, the $\mathrm{BC} / \mathrm{TOC}$ ratio ranged from 0.005 to 0.98 with a mean value at $0.23 \pm 0.24$. This was close to the one reported by Wang et al. (2014), i.e., $0.15 \pm 0.05$ according to the same BC analytical method. These authors highlighted that the BC/TOC ratios in Shanghai soils were very similar to those in the atmospheric fine particles and suggested that $\mathrm{BC}$ in those soils was closely related to deposited atmospheric particles. Considering that burning biomass and fossil fuel combustion are respectively featured by $\mathrm{BC} / \mathrm{TOC}$ to 0.11 and 0.5 , the $\mathrm{BC}$ origin seems to be a mixture of biomass and fossil fuel combustions.

\section{$\underline{\text { Trace and major elements }}$}

The first and last percentiles (d10 and d90) as well as median values (d50) as $\mathrm{mg} / \mathrm{kg}$ dry weight $(\mathrm{mg} / \mathrm{kg} . \mathrm{dw})$ for metals and major elements are illustrated on Figure 2. The mean contents $\pm \mathrm{SD}$ as $\mathrm{mg} / \mathrm{kg}$.dw for metals are compared to literature in Table 2. According to their contamination levels, three groups of metals were identified. The first group including 5 
elements (Ag, Cd, Sb, $\mathrm{Tl}$ and $\mathrm{Hg}$ ), was featured by low contents in the soil typically varying between 0.1 and $1 \mathrm{mg} / \mathrm{kg} . \mathrm{dw}$. The second group (V, Cr, $\mathrm{Mn}, \mathrm{Ba}, \mathrm{Co}, \mathrm{Ni}, \mathrm{Zn}, \mathrm{Pb}, \mathrm{Cu}, \mathrm{As}$ and Sr) exhibited contents ranging from 1 to $200 \mathrm{mg} / \mathrm{kg}$.dw. The last group (Fe, $\mathrm{Na}, \mathrm{Mg}, \mathrm{Al}, \mathrm{K}$, $\mathrm{Ca}$ and Ti) presented the highest contents $(1,000-100,000 \mathrm{mg} / \mathrm{kg} \cdot \mathrm{dw})$. That metal pattern was consistent with the typical classes observed in terrestrial environments.

As demonstrated by the first and last percentile ratios (d90 / d10 ratios), the metal contamination slightly varies. For 19 out of 23 elements monitored, the d90 / d10 ratios were lower than 5. A higher variability was observed for $\mathrm{Ca}(\mathrm{d} 90 / \mathrm{d} 10=32), \mathrm{Hg}(\mathrm{d} 90 / \mathrm{d} 10=10), \mathrm{Ag}$ (d90 / d10=7) and $\mathrm{Pb}(\mathrm{d} 90 / \mathrm{d} 10=6)$. It is highly probable that due to the sedimentary nature of the Parisian soils, the variability of $\mathrm{Ca}$ levels could reflect the local changes in the geochemical background. Other elements like $\mathrm{Pb}$ and $\mathrm{Ag}$, which also presented pronounced variabilities, might be due to changes in sulfide soil content. This would also be partly the case for $\mathrm{Cd}$ and $\mathrm{Sb}$. Besides, the distribution of most $\mathrm{Hg}$-contaminated soils closely followed that of built areas (Betard 2015).

Table 2 provides a short review of metal contamination around the world, differentiating urban, sub-urban and rural soils. For some elements, huge variations of metal contamination can be observed. Some metals considered as markers of anthropogenic activities such as $\mathrm{Cu}, \mathrm{Zn}, \mathrm{Pb}$ and $\mathrm{Hg}$ are well documented, in opposite to metals of emerging concern, such as $\mathrm{Ag}$ or $\mathrm{Sb}$. On the whole, metal contents in Parisian soils were in the middle or in the upper part of ranges reported in the literature. As an example, the $\mathrm{Pb}$ content (21-118 $\mathrm{mg} / \mathrm{kg} . \mathrm{dw}, \mathrm{d} 10-\mathrm{d} 90)$ were in accordance with the moderate to high values reported by Marcheselli et al. (2010) or by Ajmone-Marsan and Biasioli (2010) in Italy for urban or suburban soils, but lower than those quoted by Vazquez de la Cueva et al. (2014), Bermudez et al. (2012) and Rasmussen et al. (2001). Compared to literature, the contents found for $\mathrm{Cu}$ (12.0-45.4 mg/kg.dw, d10-d90), Cd (0.2-0.6 mg/kg.dw), Mn (277.2-591.9 mg/kg.dw) and Ni 
(11.3-28.0 $\mathrm{mg} / \mathrm{kg} . \mathrm{dw})$ were in the average to highest ranges. This comparison overall reinforced the concern for metals such as $\mathrm{Zn}, \mathrm{Pb}$ and $\mathrm{Cu}$. Worldwide and in the Seine River basin (Le Pape et al. 2012, Priadi et al. 2011), these elements have already been identified as long-term markers of anthropogenic emissions and, ultimately, of urbanization. Interestingly, Cd that appeared here as an anthropogenic marker in the soils, is until now not recognized as anthropogenic marker for the Seine River sediments. $\mathrm{Hg}$ instead, was characterized by relatively lower levels in the Parisian soils $(0.05-0.51 \mathrm{mg} / \mathrm{kg} . \mathrm{dw}, \mathrm{d} 10-\mathrm{d} 90)$ than in other European conurbations (0.015-6.3 mg/kg.dw, min-max (Rodrigues et al. 2006)). These low levels of $\mathrm{Hg}$ in soils could be explained by different reasons, i.e., its potential leaching during rainfall events (Barringer et al. 2010), continuous volatilization from surface soil (Gabriel et al. 2005) and low gas-phase uptake (Rutter et al. 2011). Actually, Hg would primarily either account for most recent acute pollutions (e.g., industrial releases or pesticide applications) or lower, yet chronic, contamination (i.e., transport induced emissions).

In addition to these metals, $\mathrm{Sb}$ is considered as a global emerging metal (Grahn et al. 2006; Krachler et al. 2005) and identified as an urbanization marker in the Seine River sediments (Ayrault et al., 2013; Le Pape et al. 2012). As a matter of fact, no ample comparison to the existing literature could be established due to the extremely scarce amount of data. The measured Sb contents in the urban soils (mean: $2.38,0.53-4.56 \mathrm{mg} / \mathrm{kg} . \mathrm{dw}, \mathrm{d} 10-$ d90) were notably higher than values reported for urban soils $(0.22 \mathrm{mg} / \mathrm{kg}$.dw by Rasmussen et al. 2001 or $0.88 \mathrm{mg} / \mathrm{kg}$.dw by Atapour 2015). This could reinforce the status of contaminant of emerging concern given to Sb by the US-EPA. The measured Ag contents (mean: $0.28,0.09-0.58 \mathrm{mg} / \mathrm{kg} . \mathrm{dw}, \mathrm{d} 10-\mathrm{d} 90$ ) were similar to the contents measured in the soils of Jakobstad, a small town in Finland (mean: 0.25, 0.07-1.13 mg/kg.dw, (Phuong et al. 2016)) or in the soils of Kerman city, SE Iran (mean: 0.10, max: $0.17 \mathrm{mg} / \mathrm{kg} . \mathrm{dw}$, (Sussarellu et al. 2016)) and significantly lower than the content measured in the soils of Pforzheim, SW 
Germany (mean: 2.1, <0.5-11.3 mg/kg.dw, (Mazurais et al. 2015)). Overall, the Parisian soil Ag content is significantly higher than the global geochemical background $(0.05 \mathrm{mg} / \mathrm{kg}$, (Ayrault et al. 2013)). Sb and Ag were recognized as anthropogenic markers in the Seine River basin, showing a 10-fold increase from upstream to downstream concentrations (Ayrault et al., 2013). Sb was identified as the most enriched element in the present day atmospheric particulate matter of the area (Ayrault et al. 2010). At present, no atmospheric particulate matter enrichment is observed for $\mathrm{Ag}$; and the major source of $\mathrm{Ag}$ at the scale of a basin catchment appears to be wastewater effluents (Ayrault et al., 2013). To corroborate this observation, in the Berlin city (Germany), an urban context, compost was identified as a significant source of Ag to urban soils (Birke and Rauch, 2000).). To conclude, the soil inventory highlighted the anthropogenic sources for $\mathrm{Ag}, \mathrm{Cd}, \mathrm{Cu}, \mathrm{Pb}, \mathrm{Sb}$ and $\mathrm{Zn}$ to the Parisian soils (Supplementary - Figure S1), adding Ag and Cd to the list of persistent toxic elements established through river sediment study. Indeed, the concentrations of these 6 elements in the river sediment have decreased since the pollution peak in the 1960's (Le Cloarec et al. 2011; Sussarellu et al. 2016). In spite of physical and chemical processes such as physical erosion and weathering in soils leading to pollutant attenuation, the present soil data evidenced the persistence of these elements ( $\mathrm{Ag}, \mathrm{Cd}, \mathrm{Cu}, \mathrm{Pb}, \mathrm{Sb}$ and $\mathrm{Zn}$ ) in the soils of the Seine River basin. In particular, these findings emphasized the long-term persistence of $\mathrm{Ag}$ and $\mathrm{Cd}$ in soil under long-term urban pressure.

\section{$\underline{\text { Organic pollutants }}$}

\section{Organic contamination overview}

Organic pollutant levels in soils (d10, d50 and d90, as $\mu \mathrm{g} / \mathrm{kg} . \mathrm{dw}$ ) are illustrated on Figure 3. On 82 organic micropollutants investigated, 14 substances including 9 PFASs and 5 PCBs exhibited an occurrence below 25\%, reflecting their low levels in soils. On the contrary, some substances such as NP, PAHs (acenaphthylene, phenanthrene, anthracene, fluoranthene, 
pyrene, benzo(a)anthracene, chrysene, benzo(b+k)fluoranthenes and benzo(a)pyrene), BDE 47 and BDE 209 were systematically detected in soils. On the whole, the organic micropollutant pattern was featured by the predominance of PAHs ( $\sum 15 \mathrm{PAHs}, 150-55,000$ $\mu \mathrm{g} / \mathrm{kg} . \mathrm{dw}$, min-max), followed by phthalates ( $\sum 7 \mathrm{PAEs}, 10-1,700 \mu \mathrm{g} / \mathrm{kg} . \mathrm{dw}$ ) and alkylphenols

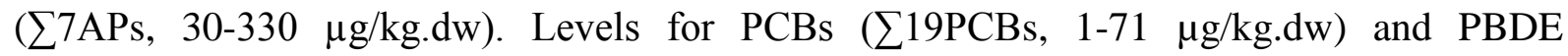
( $\sum$ PPBDEs, $\left.0.3-13 \mu \mathrm{g} / \mathrm{kg} . \mathrm{dw}\right)$ and to a greater extent PFAS ( $\sum 22 \mathrm{PFASs}, 0.2-3.2 \mu \mathrm{g} / \mathrm{kg} . \mathrm{dw}$ ) were far lower. Organic contamination levels slightly varied for alkylphenols, phthalates and PFAS (d90 / d10 ratio < 10), but the variability was higher for PCBs and PBDEs (d90 / d10 >15). The highest variability of contents was observed for PAHs (d90 / $10=90)$. PAHs are well-known combustion products and at the scale of the Parisian conurbation, PAHs are mainly emitted by road traffic. The sampling distance to the nearest trafficked road could explain the high variability observed (Clement et al. 2015, Gateuille et al. 2014b). These authors indeed observed a good relationship between normalized contents of PAHs in soils and the distance to the road edge. These authors further demonstrated that a fraction of the newly-deposited vehicular PAH was retained in the first few meters from the road whereas another part was transferred on longer ranges.

As for metals, a short review of soil contamination by organic pollutants is provided Table 3. Though the orders of magnitude reported in literature highly varied from one study to another, due to the nature of the soils studied and the year and the country considered, our levels were globally close to those previously reported. For PAHs and PCBs, results were in good agreement with local studies for urban and sub-urban soils (Meijer et al. 2003b, Motelay-Massei et al. 2004, Villanneau et al. 2011).

For PBDEs, levels observed around Paris area were also comparable to those reported in the literature (Harrad \& Hunter 2006, Hassanin et al. 2004, Zou et al. 2007, Thorenz et al., 2010). For PAEs, levels in Parisian soils are mostly in the lower range of values reported 
worldwide (Bergé et al. 2013). For APs, contents were far lower than those reported in the literature for urban land (50-9,000 $\mu \mathrm{g} / \mathrm{kg} . \mathrm{dw}$, (Sternbeck et al. 2003)) or agricultural soils for which contents varied from several hundred to several thousand $\mu \mathrm{g} / \mathrm{kg}$.dw (Bergé et al. 2012). Even if APs were studied in the past, no recent values are available for soils. The occurrence of PFASs in soils is poorly documented and, to date, mainly PFOA and PFOS have been targeted although very few data are also available for a limited set of fluoroalkyl carboxylates (Strynar et al. 2012, Washington et al. 2008). Strynar et al. (2012) estimated global median concentrations of 0.12 and $0.47 \mu \mathrm{g} / \mathrm{kg}$.dw for PFOA and PFOS, respectively, which is in excellent agreement with those determined in the present study: $0.15 \mu \mathrm{g} / \mathrm{kg}$.dw for PFOA and $0.65 \mu \mathrm{g} / \mathrm{kg} . \mathrm{dw}$ for PFOS.

\section{Pollutant patterns}

The distribution of compounds for each group is illustrated on Figure 4. For APs, NP, nonylphenol monoethoxylate (NP1EO) and nonylphenol diethoxylate (NP2EO) were predominant (occurrence varied between 80 and 100\%) while octylphenol (OP), octylphenol monoethoxylate (OP1EO) and octylphenol diethoxylates (OP2EO) as well as nonylphenoxy acetic acid (NP1EC) exhibited low occurrence (<LOQ-30\%). The patterns were featured by NP predominance $(23-123 \mu \mathrm{g} / \mathrm{kg} . \mathrm{dw}, \mathrm{d} 10-\mathrm{d} 90)$ accounting for $50 \%$ of APs. These patterns were clearly different from those observed in surface water or in total atmospheric fallout (Cladière et al. 2013), likely as a result of AP degradation in soil. Actually, NP is the biodegradation end product of NPnEOs. About $80 \%$ of NP can be degraded in soils, the remaining part being refractory (Marcomini et al. 1989).

For PAEs, the following sequence was observed: DEHP $(35-411 \mu \mathrm{g} / \mathrm{kg} . \mathrm{dw})>\mathrm{DiBP}$ $(19-329 \mu \mathrm{g} / \mathrm{kg} . \mathrm{dw}, \mathrm{d} 10-\mathrm{d} 90)>\operatorname{DnBP}(5-142 \mu \mathrm{g} / \mathrm{kg} . \mathrm{dw}) \cong \mathrm{DEP}(6-112 \mu \mathrm{g} / \mathrm{kg} . \mathrm{dw})>\mathrm{BBP}(2-$ $20 \mu \mathrm{g} / \mathrm{kg} . \mathrm{dw}) \cong \mathrm{DMP}(1-15 \mu \mathrm{g} / \mathrm{kg} \cdot \mathrm{dw})$ and DnOP $(2-8 \mu \mathrm{g} / \mathrm{kg} . \mathrm{dw})$. DiBP and DEHP account for 29 and 20\%, respectively. The predominance of DEHP and DiBP in soils was already 
observed in some studies (Bergé et al. 2013, Zeng et al. 2009). This is consistent with the application of similar commercial PAEs around the world. The PAE patterns were also in good agreement with those reported for total atmospheric fallout and surface water (Tran et al. 2015).

The PAH patterns were fairly similar among sites, featured by the predominance of high molecular weight PAHs (HMW PAHS, i.e., 4-6 benzenic rings) comparatively to the low molecular weight PAHs (LMW PAHs, i.e., 2-3 benzenic rings). According to the literature, samples contaminated by petrogenic sources are characterized by a higher proportion of LMW PAHs, while a pyrolytic contamination exhibits higher contribution of HMW PAHs (Soclo et al. 2000). In soils, the LMW/HMW PAH ratio was equal to 0.11, suggesting a pyrolytic origin of PAHs. The presence of Fluo and Pyr supported this hypothesis since both compounds are considered as pyrolytic markers. In spite of several limitations (Clement et al. 2015, Yunker et al. 2002b), different PAH ratios, such $\mathrm{P} /(\mathrm{P}+\mathrm{A})$ or Fluo/(Fluo+Pyr), can be also used to probe PAH origins (Yunker et al. 2002a). The latter suggested a mixture of pyrolytic and petrogenic contamination but are close to the pattern observed for ambient air (Supplementary - Figure S1).

PCB patterns in soils were featured by the predominance of 7 PCBs listed as indicators in environmental contamination studies.. $\sum 7 \mathrm{PCBs}$ accounted for 70 to $100 \%$ of total PCBs. $\sum 8$ dioxin like PCBs contributed to less than $15 \%$ of total PCBs, while PCB 153 (0.37-6.40 $\mu \mathrm{g} / \mathrm{kg} . \mathrm{dw})$ and PCB $138(0.31-5.60 \mu \mathrm{g} / \mathrm{kg} . \mathrm{dw})$ were the dominant congeners, followed by PCB $118(0.40-2.65 \mu \mathrm{g} / \mathrm{kg} . \mathrm{dw})$ and $180(0.25-4.89 \mu \mathrm{g} / \mathrm{kg} . \mathrm{dw})$. Patterns in soils were also clearly different from those observed for ambient air dominating by most volatile compounds $($ PCB $52>101>28>153>138>118>180$, (Teil et al. 2016)).

For PBDEs, BDE 209 was predominant, accounting for 70\% of total PBDEs. BDE 28, 154 and 153 had an occurrence below 30\%. The PBDE pattern in soils was similar to that 
commonly found in environmental matrices and anthropogenic areas (Hassanin et al. 2004, Muresan et al. 2010, Zou et al. 2007). It is worth noting a spatial correlation between several normalized PBDE contents, i.e., including all the congeners from BDE 28 to BDE 183 (p < 0.1). The identified correlations were especially significant for PBDEs ranging from BDE 47 to BDE $153(\mathrm{p}<0.05)$, which pointed out the existence of a common source. Their relative contributions to the sum of all the tested congeners linearly increases with the decrease in BDE 209 contribution thereby indicating the degradation of newly-deposited BDE 209 into lower molecular weight PBDEs. This relationship was less meaningful between BDE 209 and BDE 28, 183 or 205 contributions ( $p>0.1$ ).

Out of the 22 PFAS monitored, 6 compounds (PFPeA, PFHxA, PFHpA, PFTrDA, PFTeDA, EtFOSA) were never detected and 2 (6:2 FTS and MeFOSAA) occasionally detected. The occurrence of remaining compounds ranged from $25 \%$ to $50 \%$ for $\mathrm{PFHpS}$, EtFOSAA, PFDoA while PFOA, PFHxS, PFNA, PFDA, PFUnA and PFOS were almost always quantified. PFOS $(0.28-2.05 \mu \mathrm{g} / \mathrm{kg} . \mathrm{dw}, \mathrm{d} 10-\mathrm{d} 90)$ followed by PFOA (0.07-0.46 $\mu \mathrm{g} / \mathrm{kg} . \mathrm{dw}$ ) were predominant while other compounds lied in lower ranges. These patterns were in good agreement with those reported in soils by Strynar et al. (2012), i.e. PFOS > PFOA > PFDoA > PFHpA > PFHxA but were quite different from those observed in surface water with predominance of PFOS and PFHxS (Loos et al. 2013, Munoz et al. 2015b) or in total atmospheric fallout with the predominance of PFOA and PFNA (Kwok et al. 2010). The differences of PFAS patterns might be linked to i) the degradation of PFOS precursors and ii) the higher lixiviation of shorter-chain carboxylic acids such as PFOA comparatively to PFOS, due to their lower solid-liquid partitioning coefficients (Munoz et al. 2015b).

\subsection{Correlation between soil TOC, BC and pollutants}

Considering the 32 soil samples (urban and rural soils), no significant correlation was found neither between TOC and $\mathrm{BC}$ nor between $\mathrm{TOC}, \mathrm{BC}$, metals and organic pollutants 
(Pearson test, $\alpha=0.05$ ). To date, no other study reported significant correlation between TOC, BC and metals. For organic pollutants, several studies examined such correlation but not for all groups of pollutants monitored in the present study. A correlation between TOC and BC in soil samples from background locations in the UK and Norway was reported (Nam et al. (2008). These authors also observed a correlation between TOC and PBDEs and to a lesser extent between TOC, PAHs and PCBs. The difference of TOC levels between Parisian soils (0.54-9.14 \%) and those studied in the UK and Norway (5.4-46\%), could explain this different trend. In China, Wang et al. (2014) reported no correlation for urban soils between TOC, BC and PAHs, contrary to the sub-urban and industrial soils. For these sites, authors quoted that BC and LMW PAHs were strongly correlated, but so less for HMW PAHs. Similarly, Villanneau et al. (2011) highlighted for French soils a correlation between TOC and PCBs but none between TOC and PAHs. In China, a study reported that the concentrations of PAEs were poorly correlated with soil organic carbon content, suggesting mixing process between local and on-going sources (Zeng et al. 2009).

Although BC is generally considered as a "super sorbent" playing an important role in organic pollutant partitioning in soils, the lack of correlation between $\mathrm{BC}$ and pollutants investigated can be due to i) differences of pollutant and BC emissions and/or ii) differences of behavior during atmospheric transport and deposition and iii) differences of behavior and partitioning in soils. Actually, some pollutants may be accidently formed or released from various incomplete combustion processes and therefore a more or less proportion can be emitted in the form of BC-pollutant complexes. For some pollutants such as PCBs, PBDEs and PAEs, a hypothesis explaining the lack of straight correlations could be that these pollutants, which are preferentially emitted from volatilization processes, are either readily exported from contaminated surface soils or (bio)degraded soon after deposition. Finally, as suggested by Nan et al. (2008), the lack of associations between BC and organic pollutant 
could simply reflect the strong signature of the historical BC, mainly from (cumulative) combustion inputs over many centuries.

\subsection{Contamination and land use}

For a number of metals and organic contaminants, no significant difference of contamination between urban $(n=20)$ and rural $(n=12)$ soils was observed (Man-Whitney test, $\alpha=0.05$ ). However, significantly higher levels were observed in urban soils for BC (mean at 0.34\% in urban soils vs. 0.14\% in rural soils), $\mathrm{Cu}$ (25.5 vs. $15.3 \mathrm{mg} / \mathrm{kg} . \mathrm{dw}), \mathrm{Zn}$ (102 vs. 61 mg/kg.dw), Hg (0.15 vs. $0.07 \mathrm{mg} / \mathrm{kg} . \mathrm{dw})$ and PFOS (0.95 vs. $0.33 \mu \mathrm{g} / \mathrm{kg} . \mathrm{dw})$. Based on the 32 soil samples, trends also appeared for PBDEs ( $\sum 8$ PBDEs, $0.95 v s .0 .53 \mu \mathrm{g} / \mathrm{kg} . \mathrm{dw}$ ), PCBs ( $\sum 19 \mathrm{PCBs}, 10.29$ vs. $\left.4.65 \mu \mathrm{g} / \mathrm{kg} . \mathrm{dw}\right)$, PFAS ( $\sum 22 \mathrm{PFASs}, 1.00$ vs. $\left.0.37 \mu \mathrm{g} / \mathrm{kg} . \mathrm{dw}\right), \mathrm{Sr}(120.8$ vs.66.5 mg/kg.dw) and $\mathrm{Sb}(2.38$ vs. $0.88 \mu \mathrm{g} / \mathrm{kg} . \mathrm{dw})$ but these differences are not statistically significant (Man-Whitney test, $\alpha=0.05$ ). For $\sum 15$ PAHs, similar levels are found between rural and urban soils (1,833 vs. 1,010 $\mu \mathrm{g} / \mathrm{kg} . \mathrm{dw})$, as well as for $\sum 7$ PAEs (395 vs. $\left.371 \mu \mathrm{g} / \mathrm{kg} . \mathrm{dw}\right)$. For PBDEs, Muresan et al. (2010) analyzed all soils from the Paris soil bank $(\mathrm{n}=120$ including the 32 soils considered), they observed that PBDE levels increased in relation to urbanization. In the latter study, no significant difference in $\sum$ 8PBDEs concentrations was observed between forested and rural soils (0.59 and $0.66 \mu \mathrm{g} / \mathrm{kg} . \mathrm{dw})$. On the whole, these results highlight both the higher contamination of urban soils, probably due to their location close to the urban sources, and also the significant dissipation of several classes of POPs in the environment at a regional scale. As previously suggested, land use alone is often a rather unreliable indicator to discriminate soil pollution (Desaules et al. 2010).

Although the effect of land use could not be evidenced for all contaminants, some soil samples were clearly more contaminated than others, and reflected a multi-contamination. Principal component analysis (PCA) was performed on metal and organic pollutant dataset (Supplementary - Figure 2) and pointed out different soil samples (\#109,\#100 and \#70) which 
exhibited significantly higher levels of pollutants in comparison to other ones. The extremely high contamination of the \#100 soil sample, corresponding to a heavily urbanized parcel surrounded by industrial and commercial areas, could be related to transport sector emissions. Indeed, the sampling site is closely related to: i) a highly-trafficked road (Motorway A86), a railway station providing access to the largest wholesale food market in the world (Rungis) and the $2^{\text {nd }}$ largest airport in the Ile de France Region (Orly). The marked Sr levels (217.1 $\mathrm{mg} / \mathrm{kg} . \mathrm{dw}$ ), also considered as traffic related metal, support this assumption (Thorpe and Harrison, 2008). This was further testified by the high PAH ( $\left.\sum 15 \mathrm{PAHs}, 55,800 \mu \mathrm{g} / \mathrm{kg} . \mathrm{dw}\right)$, PCB ( $\left.\sum 19 \mathrm{PCBs}, 25.8 \mu \mathrm{g} / \mathrm{kg} . \mathrm{dw}\right), \mathrm{Cu}(27.4 \mathrm{mg} / \mathrm{kg})$ and $\mathrm{Zn}(117 \mathrm{mg} / \mathrm{kg} . \mathrm{dw})$ levels that usually depict industrial soils as well as emissions from vehicular exhaust and/or the wear of moving parts. As for \#109 soil sample, the increased PAH ( $\sum 15 \mathrm{PAHs}, 7,740 \mu \mathrm{g} / \mathrm{kg} . \mathrm{dw}$ ) contents presumably accounted from the proximity to the largest French river port (Gennevilliers) that concentrate commercial activities, fuel storage tanks and large goods vehicle / barge traffic. The relating site was also located in close proximity to the northern section of Motorway A86. The high contamination of the \#70 soil sample, corresponding to an agricultural parcel remote from heavily densely area, could be related to sludge amendment. Indeed, significant amount of PAHs were reported for sludge with individual concentrations ranging from 11 to 990 $\mu \mathrm{g} / \mathrm{kg} . \mathrm{dw}$ (Mailler et al. 2014). However, the contamination of this soil by other pollutants brought by sewage sludge, such as PBDEs, PAEs, PFASs and metals was not observed, suggesting probable other contamination source.

\subsection{Stocks in soils vs. atmospheric fluxes}

Since many studies reported the importance of soils in the global cycle and budget of POPs (Meijer et al. 2003a; Rutter et al. 2011; Strynar et al. 2012), the aims of this last section was to assess the stock of pollutants in surface soils form Greater Paris area and to evaluate the relative importance of these stocks compared to estimated annual atmospheric fallout. The 
pollutant stocks as $\mathrm{mg}$ or $\mu \mathrm{g} / \mathrm{m}^{2}$ was arbitrarily estimated for the $0-10 \mathrm{~cm}$ upper layer of soils, considering the median values obtained on the 32 soils studied and a wet soil density of 2,000 $\mathrm{kg} / \mathrm{m}^{3}$ (Table 4). Each pollutant stock per surface unit $\left(\mathrm{mg} / \mathrm{m}^{2}\right.$ or $\left.\mu \mathrm{g} / \mathrm{m}^{2}\right)$ was calculated according to equation 1.

$$
\operatorname{Stock}_{\text {Polluant i }}\left(\mathrm{mg} / \mathrm{m}^{2} \text { or } \mu \mathrm{g} / \mathrm{m}^{2}\right)=\delta \times \mathrm{S} \times \rho_{\text {Wet }} \times[\text { Pollutant }] \quad \text { (Equation 1) }
$$

With

$\delta$ : depth of soil considered $(\delta=0.10 \mathrm{~m})$

S: surface of soil considered $\left(\mathrm{S}=1 \mathrm{~m}^{2}\right)$

$\rho_{\text {Wet }}$ Wet soil density $\left(\rho_{\text {Wet }}=2,000 \mathrm{~kg} / \mathrm{m}^{3}\right)$

[Pollutant i]: median content of pollutant «i » in wet soil, in $\mathrm{mg} / \mathrm{kg}$ or $\mu \mathrm{g} / \mathrm{kg}$

For each group of compounds, annual atmospheric fluxes as $\mathrm{mg}$ or $\mu \mathrm{g} / \mathrm{m}^{2} / \mathrm{year}$ were also provided by previous works within the framework of the PIREN-Seine program (Moreau-Guigon et al. 2016). The ratios between the stocks and the minimal and maximal atmospheric fluxes were also estimated for some relevant metals ( $\mathrm{Pb}, \mathrm{Hg}, \mathrm{Zn}, \mathrm{Cd}$ and $\mathrm{Sb}$ ) and for each family of organic pollutants.

For PAHs and $\mathrm{Pb}$, a significant stock of pollutants was present in soils, far higher than annual atmospheric fluxes. Based on the highest values of atmospheric fluxes their stock / deposition flux ratios exceeded 1,000. This evidenced the importance of the soil reservoir compared to recent atmospheric inputs. For $\mathrm{Zn}, \mathrm{Cu}, \mathrm{Cd}, \mathrm{Hg}, \mathrm{Sb}, \sum 7 \mathrm{PAEs}$ and $\sum 7 \mathrm{APs}$, the annual atmospheric inputs contribute up to $1.5 \%$ of soil pollutant stocks. It is highly probable that these stocks resulted from i) the persistence of a fraction of pollutants in surface soils and/or ii) the cumulative atmospheric inputs over several decades. For instance, different studies demonstrated that the emission of $\mathrm{PAHs}$ and $\mathrm{Pb}$ in the past were more important, due to the biomass, coal and lead derived fossil fuel combustion (Azimi et al. 2005, Han et al. 
2015). A similar decline of PCB contamination was observed in flood plain in the Seine River (Lorgeoux et al. 2016). Similarly, the metal contamination of the Seine River suspended sediment archives decreased significantly from 1960 to day, including for $\mathrm{Zn}, \mathrm{Cu}, \mathrm{Cd}, \mathrm{Sb}$ (Le Cloarec et al. 2011).

Furthermore, some pollutants such as $\mathrm{Hg}$, PAEs and APs were industrially used since 1940's and 1960's in large range of domestic and industrial applications, leading to a wild dissemination of these xenobiotics. With regard to PBDEs and PFASs, a higher contribution of atmospheric inputs to the pollutant stocks is observed, i.e. from 3.9 to $7.8 \%$ for PFASs and from 2.8 to $3.5 \%$ for PBDEs depending on the hypothesis. The relatively large contributions of PBDE deposition fluxes likely resulted in the observed variations between data by Muresan et al. (2010) and Tlili et al. (2012) at the Parisian area scale. The first use and mass production of PBDEs started in 1980's (Hites 2004). Due to the different legislation restrictions (Water Framework Directive, Stockholm convention, etc.), however, their use would significantly decrease in the future. As concerns PFASs, their intensive implementation started earlier in 1950's (Armitage et al. 2009, Buck et al. 2011). Furthermore, short-chained PFASs might be very persistent and much more mobile than the long-chained ones or other hydrophobic contaminants (Ahrens 2011), which could lead to the underestimation of the actual contribution of atmospheric fallout to the PFAS stock in the top surface layer of soils.

\section{Conclusions}

This study delivered the following findings:

i) By examining the soil contamination, results reinforced the concern of metals such as $\mathrm{Zn}, \mathrm{Pb}$ and $\mathrm{Cu}$, identified as long-term metallic markers of (not mining, not smelting) anthropogenic activity. These additionally pointed the ubiquitous contamination of soils by several organic micropollutants: from 0.2 to $55,000 \mu \mathrm{g} / \mathrm{kg} . \mathrm{dw}$. The following pattern was 
highlighted: PAHs ( $\sum 15$ PAHs, 150-55,000 $\left.\mu \mathrm{g} / \mathrm{kg} . \mathrm{dw}\right)>$ PAEs $\left(\sum 7 \mathrm{PAEs}, 10-1,700 \mu \mathrm{g} / \mathrm{kg} . \mathrm{dw}\right)$ $>\operatorname{APs}\left(\sum 7 \mathrm{APs}, 30-330 \mu \mathrm{g} / \mathrm{kg} . \mathrm{dw}\right)>>$ PCBs $\left(\sum 19 \mathrm{PCBs}, 1-71 \mu \mathrm{g} / \mathrm{kg} . \mathrm{dw}\right)>$ PBDEs ( $\sum 8$ PBDEs, $\left.0.3-13 \mu \mathrm{g} / \mathrm{kg} . \mathrm{dw}\right)>$ PFASs ( $\left.\sum 22 \mathrm{PFASs}, 0.2-3.2 \mu \mathrm{g} / \mathrm{kg} . \mathrm{dw}\right)$.

ii) No specific correlation was observed between organic matter parameters (TOC and BC) neither between organic matter and pollutants. This lack of correlation could be due to i) different pollutant and $\mathrm{BC}$ emission histories and/or ii) different behaviors during atmospheric transport and deposition and iii) different behaviors and partitioning in soils. This could also reflect the strong signature of the historical $\mathrm{BC}$, mainly from (cumulative) combustion inputs over many centuries. For most of pollutants, no significant differences were observed between urban $(\mathrm{n}=20)$ and rural $(\mathrm{n}=12)$ top $10 \mathrm{~cm}$ soils except, however, for $\mathrm{BC}, \mathrm{Cu}, \mathrm{Zn}$ and PFOA. Slight differences, yet not significant at $\alpha=0.05$ level of confidence, were also reported for

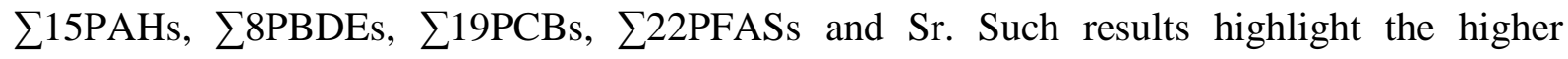
contamination of urban soils for these pollutants, probably due to their location close to the urban sources, but they also provide further evidence for the widespread dissemination of many contaminants in the environment.

iii) The present results clearly identified the contaminants, both organic and inorganic, that could be qualified of "urban contaminants". Nevertheless, it is still not possible to define concentration threshold determining the contamination of an urban soil. Indeed, the contaminant concentration in a soil under urban influence depends on a complex mixture of factors including the emerging vs. legacy status of the contaminant, its source type(s), its chemical properties, the "history" of the soil sample, etc. These numerous factors are somewhat poorly understood for the whole large list of "urban" contaminants.

iv) By comparing the pollutant stocks in the first 10-cm layer of soils to the atmospheric inputs, this study highlighted that significant stocks of PAHs and $\mathrm{Pb}$ were present in soils 
(ratio above 1,000). For $\mathrm{Zn}, \mathrm{Cu}, \mathrm{Cd}, \mathrm{Hg}$, Sb, $\sum 7 \mathrm{PAEs}$ and $\sum 7 \mathrm{APs}$, annual atmospheric inputs contribute to up $1.5 \%$ of soil pollutant stocks. Higher contributions (up to $7.8 \%$ ) are observed for $\sum$ 8PBDEs and $\sum 22$ PFASs. Actually, the stocks of these pollutants result from i) their persistence in soils and ii) the cumulative atmospheric inputs over several decades. The link between this pollutant reservoir and the export pollutant rate from soil to river through erosive processes needs to be better assessed, so as to better estimate the depuration times and the time needed to reach "the good chemical status" of surface water within the European Union Water Framework Directive.

One perspective of this work would be a study devoted to the processes leading to the attenuation or to the persistence of the contaminants in soils. Such an inter-disciplinary study would integrate the pedological and structural characteristics of the soil as drivers of these processes.

\section{Acknowledgments}

This study was carried out within the framework of the PIREN-Seine research program. Authors gratefully acknowledge Tony Nemouthe and Quentin Claveau for PFAS and metal analyses, respectively.

\section{References}

Ahrens L (2011): Polyfluoroalkyl compounds in the aquatic environment: a review of their occurrence and fate. Journal of Environmental Monitoring 13, 20-31

Ajmone-Marsan F, Biasioli M (2010): Trace Elements in Soils of Urban Areas. Water Air and Soil Pollution 213, 121-143

Allan M, Le Roux G, Sonke J, Piotrowska N, Streel M, Fagel N (2013): Reconstructing historical atmospheric mercury deposition in Western Europe using: Misten peat bog cores, Belgium. Science of the Total Environment 442, 290-301

Alliot F, Moreau-Guigon E, Bourges C, Desportes A, Teil M-J, Blanchard M, Chevreuil M (2014): A multi-residue method for characterization of endocrine disruptors in gaseous and particulate phases of ambient air. Atmospheric Environment 92, 1-8 
Andreu V, Ferrer E, Rubio JL, Font G, Pico Y (2007): Quantitative determination of octylphenol, nonylphenol, alkylphenol ethoxylates and alcohol ethoxylates by pressurized liquid extraction and liquid chromatography-mass spectrometry in soils treated with sewage sludges. Science of the Total Environment 378, 124-129

Armitage JM, MacLeod M, Cousins IT (2009): Comparative Assessment of the Global Fate and Transport Pathways of Long-Chain Perfluorocarboxylic Acids (PFCAs) and Perfluorocarboxylates (PFCs) Emitted from Direct Sources. Environmental Science \& Technology 43, 5830-5836

Ayrault S, Senhou A, Moskura M, Gaudry A (2010): Atmospheric trace element concentrations in total suspended particles near Paris, France. Atmospheric Environment 44, 3700-3707

Ayrault S, Priadi C, Le Pape P, Bonté P (2013): Occurrence, sources and pathways of antimony and silver in an urban catchment. Urban Environment, R.M.E., Springer, 425-435.

Azimi S, Rocher V, Garnaud S, Varrault G, Thévenot DR (2005): Decrease of atmospheric deposition of heavy metals in an urban area from 1994 to 2002 (Paris, France). Chemosphere 61, 645-651

Barringer JL, Riskin ML, Szabo Z, Reilly PA, Rosman R, Bonin JL, Fischer JM, Heckathorn HA (2010): Mercury and Methylmercury Dynamics in a Coastal Plain Watershed, New Jersey, USA. Water Air and Soil Pollution 212, 251-273

Bergé A, Cladière M, Gaspéri J, Coursimault A, Tassin B, Moilleron R (2012): Meta-analysis of environmental contamination by alkylphenols. Environmental Science and Pollution Research 19, 3798-3819

Bergé A, Cladière M, Gaspéri J, Coursimault A, Tassin B, Moilleron R (2013): Meta-analysis of environmental contamination by phthalates. Environmental Science and Pollution Research 20, 8057-8076

Bermudez GMA, Jasan R, Pla R, Pignata ML (2012): Heavy metals and trace elements in atmospheric fall-out: Their relationship with topsoil and wheat element composition. Journal of Hazardous Materials 213, 447-456

Betard F (2015): Protection and promotion of geomorphological heritage in the Île-de-France region (Paris Basin, France): Overview and prospects. Vertigo 15, 38 p (in French).

Birke M. and Rauch U. (2000): Urban geochemistry: investigations in the berlin metropolitan area. Environmental Geochemistry and Health 22: 233-248, 2000

Blanchard M, Teil MJ, Chevreuil M (2006): The seasonal fate of PCBs in ambient air and atmospheric deposition in northern France. Journal of Atmospheric Chemistry 53, 123-144

Brandli RC, Hartnik T, Henriksen T, Cornelissen G (2008): Sorption of native polyaromatic hydrocarbons (PAH) to black carbon and amended activated carbon in soil. Chemosphere 73, 1805-1810Brus DJ, Lame FPJ, Nieuwenhuis RH (2009): National 
baseline survey of soil quality in the Netherlands. Environmental Pollution 157, 20432052

Bucheli TD, Blum F, Desaules A, Gustafsson O (2004): Polycyclic aromatic hydrocarbons, black carbon, and molecular markers in soils of Switzerland. Chemosphere 56, 1061 1076

Buck RC, Franklin J, Berger U, Conder JM, Cousins IT, de Voogt P, Jensen AA, Kannan K, Mabury SA, van Leeuwen SPJ (2011): Perfluoroalkyl and polyfluoroalkyl substances in the environment: terminology, classification, and origins. Integrated environmental assessment and management 7, 513-41

Cladière M, Gaspéri J, Lorgeoux C, Bonhomme C, Rocher V, Tassin B (2013): Alkylphenolic compounds and bisphenol A contamination within a heavily urbanized area: case study of Paris. Environmental Science and Pollution Research 20, 2973-2983

Cladière M 2012: Flux et devenir des alkylphénols et du bisphénol A dans le bassin de la Seine. Thèse Université Paris Est, 254 p.

Clement N, Muresan B, Hedde M, Francois D (2015): PAH dynamics in roadside environments: Influence on the consistency of diagnostic ratio values and ecosystem contamination assessments. Science of the Total Environment 538, 997-1009

Cornelissen G, VanNoort PCM, Parsons JR, Govers HAJ (1997): Temperature dependence of slow adsorption and desorption kinetics of organic compounds in sediments. Environmental Science \& Technology 31, 454-460

Cornelissen G, Gustafsson O (2005): Importance of unburned coal carbon, black carbon, and amorphous organic carbon to phenanthrene sorption in sediments. Environmental Science \& Technology 39, 764-769

Dargnat C 2008: Sources, transferts et devenir des phtalates sur le bassin versant de la seine. Caractérisation des dangers pour l'environnement et les écosystèmes, Thèse de doctorat, Université Pierre et Marie Curie, spécialité Géosciences et ressources naturelles, Paris, 269 pp (in French)

Desaules A, Ammann S, Schwab P (2010): Advances in long-term soil-pollution monitoring of Switzerland. Journal of Plant Nutrition and Soil Science 173, 525-535

Gabriel MC, Williamson DG, Brooks S, Zhang H, Lindberg S (2005): Spatial variability of mercury emissions from soils in a southeastern US urban environment. Environmental Geology 48, 955-964

Gatari MJ, Boman J (2003): Black carbon and total carbon measurements at urban and rural sites in Kenya, East Africa. Atmospheric Environment 37, 1149-1154

Gateuille D, Evrard O, Lefevre I, Moreau-Guigon E, Alliot F, Chevreuil M, Mouchel J-M (2014a): Mass balance and decontamination times of Polycyclic Aromatic Hydrocarbons in rural nested catchments of an early industrialized region (Seine River basin, France). Science of the Total Environment 470, 608-617 
Gateuille D, Evrard O, Lefevre I, Moreau-Guigon E, Alliot F, Chevreuil M, Mouchel JM (2014b): Combining measurements and modelling to quantify the contribution of atmospheric fallout, local industry and road traffic to PAH stocks in contrasting catchments. Environmental Pollution 189, 152-160

Goutte A, Chevreuil M, Alliot F, Chastel O, Cherel Y, Eleaume M, Masse G (2013): Persistent organic pollutants in benthic and pelagic organisms off Adelie Land, Antarctica. Marine Pollution Bulletin 77, 82-89

Grahn E, Karlsson S, Duker A (2006): Sediment reference concentrations of seldom monitored trace elements (Ag, Be, In, Ga, Sb, T1) in four Swedish boreal lakes Comparison with commonly monitored elements. Science of the Total Environment 367, 778-790

Gustafsson Ö, Bucheli TD, Kukulska Z, Andersson M, Largeau C, Rouzaud J-N, Reddy CM, Eglinton TI (2001): Evaluation of a protocol for the quantification of black carbon in sediments. Global Biogeochemical Cycles 15, 881-890

Hamilton GA, Hartnett HE (2013): Soot black carbon concentration and isotopic composition in soils from an arid urban ecosystem. Organic Geochemistry 59, 87-94

Han YM, Wei C, Bandowe BAM, Wilcke W, Cao JJ, Xu BQ, Gao SP, Tie XX, Li GH, Jin ZD, An ZS (2015): Elemental carbon and polycyclic aromatic compounds in a 150year sediment core from lake qinghai, tibetan plateau, china: influence of regional and local sources and transport pathways. Environmental Science \& Technology 49, 417683

Harris-Hellal J, Grimaldi M, Garnier-Zarli E, Bousserrhine N (2011): Mercury mobilization by chemical and microbial iron oxide reduction in soils of French Guyana. Biogeochemistry 103, 223-234

Hassanin A, Breivik K, Meijer SN, Steinnes E, Thomas GO, Jones KC (2004): PBDEs in European background soils: Levels and factors controlling their distribution. Environmental Science \& Technology 38, 738-745

Hernandez-Quiroz M, Herre A, Cram S, Ponce de Leon C, Siebe C (2012): Pedogenic, lithogenic - or anthropogenic origin of $\mathrm{Cr}, \mathrm{Ni}$ and $\mathrm{V}$ in soils near a petrochemical facility in Southeast Mexico. Catena 93, 49-57

Hites RA (2004): Polybrominated diphenyl ethers in the environment and in people: A metaanalysis of concentrations. Environmental Science \& Technology 38, 945-956

Imperato M, Adamo P, Naimo D, Arienzo M, Stanzione D, Violante P (2003): Spatial distribution of heavy metals in urban soils of Naples city (Italy). Environmental Pollution 124, 247-256

Krachler M, Zheng J, Koerner R, Zdanowicz C, Fisher D, Shotyk W (2005): Increasing atmospheric antimony contamination in the northern hemisphere: snow and ice evidence from Devon Island, Arctic Canada. Journal of Environmental Monitoring 7, $1169-1176$ 
Kwok KY, Taniyasu S, Yeung LWY, Murphy MB, Lam PKS, Horii Y, Kannan K, Petrick G, Sinha RK, Yamashita N (2010): Flux of Perfluorinated Chemicals through Wet Deposition in Japan, the United States, And Several Other Countries. Environmental Science \& Technology 44, 7043-7049

Le Cloarec MF, Bonte PH, Lestel L, Lefevre I, Ayrault S (2011): Sedimentary record of metal contamination in the Seine River during the last century. exported from refbase (http://leesu.univ-paris-est.fr/refbase/show.php?record=176), last updated on Thu, 10 Dec 2009 18:18:54 +0100 36, 515-529

Le Pape P, Ayrault S, Quantin C (2012): Trace element behavior and partition versus urbanization gradient in an urban river (Orge River, France). Journal of Hydrology $472,99-110$

Le Pape P, Quantin C, Morin G, Jouvin D, Kieffer I, Proux O, Ghanbaja J, Ayrault S (2014): Zinc Speciation in the Suspended Particulate Matter of an Urban River (Orge, France): Influence of Seasonality and Urbanization Gradient. Environmental Science \& Technology 48, 11901-11909

Li F, Zhang C, Qu Y, Chen J, Chen L, Liu Y, Zhou Q (2010): Quantitative characterization of short- and long-chain perfluorinated acids in solid matrices in Shanghai, China. Science of the Total Environment 408, 617-623

Loos R, Carvalho R, António DC, Comero S, Locoro G, Tavazzi S, Paracchini B, Ghiani M, Lettieri T, Blaha L, Jarosova B, Voorspoels S, Servaes K, Haglund P, Fick J, Lindberg RH, Schwesig D, Gawlik BM (2013): EU-wide monitoring survey on emerging polar organic contaminants in wastewater treatment plant effluents. Water Research 47, 6475-6487

Lorgeoux C, Moilleron R, Gaspéri J, Ayrault S, Bonté P, Lefevre I, Tassin B (2016): Temporal trends of persistent organic pollutants in dated sediment cores: Chemical fingerprinting of the anthropogenic impacts in the Seine River basin, Paris. Science of the Total Environment 541, 1355-1363

Mailler R, Gaspéri J, Chebbo G, Rocher V (2014): Priority and emerging pollutants in sewage sludge and fate during sludge treatment. Waste Management 34, 1217-1226

Mailler R 2015: Removal of priority and emerging micropollutants in the conventionnal wastewater treatments (water and sludge), and during the tertiary treatment by activated carbon, Université Paris-Est, 373 pp (in French)

Marcheselli M, Sala L, Mauri M (2010): Bioaccumulation of PGEs and other traffic-related metals in populations of the small mammal Apodemus sylvaticus. Chemosphere 80, $1247-1254$

Marcomini A, Capel PD, Lichtensteiger T, Brunner PH, Giger W (1989): Behaviour of aromatic surfactants and PCBs in sludge-treated soil and landfills. J. Environ. Qual. $18,523-528$

Mazurais D, Ernande B, Quazuguel P, Severe A, Huelvan C, Madec L, Mouchel O, Soudant P, Robbens J, Huvet A, Zambonino-Infante J (2015): Evaluation of the impact of 
polyethylene microbeads ingestion in European sea bass (Dicentrarchus labrax) larvae. Marine Environmental Research 112, 78-85

Meijer SN, Ockenden WA, Steinnes E, Corrigan BP, Jones KC (2003a): Spatial and temporal trends of POPs in Norwegian and UK background air: Implications for global cycling. Environmental Science \& Technology 37, 454-461

Meijer SN, Ockenden WA, Sweetman A, Breivik K, Grimalt JO, Jones KC (2003b): Global distribution and budget of PCBs and HCB in background surface soils: Implications or sources and environmental processes. Environmental Science \& Technology 37, 667672

Meybeck M, Lestel L, Bonte P, Moilleron R, Colin JL, Rousselot O, Herveé D, de Ponteves C, Grosbois C, Thévenot DR (2007): Historical perspective of heavy metals contamination $(\mathrm{Cd}, \mathrm{Cr}, \mathrm{Cu}, \mathrm{Hg}, \mathrm{Pb}, \mathrm{Zn}$ ) in the Seine River basin (France) following a DPSIR approach (1950-2005). Science of the Total Environment 375, 204-231

Motelay-Massei A, Ollivon D, Garban B, Teil MJ, Blanchard M, Chevreuil M (2004): Distribution and spatial trends of PAHs and PCBs in soils in the Seine River basin, France. Chemosphere 55, 555-565

Motelay-Massei A, Ollivon D, Garban B, Tiphagne-Larcher K, Chevreuil M (2007): Fluxes of polycyclic aromatic hydrocarbons in the Seine estuary, France: mass balance and role of atmospheric deposition. Hydrobiologia 588, 145-157

Munoz G, Duy SV, Budzinski H, Labadie P, Liu J, Sauve S (2015a): Quantitative analysis of poly- and perfluoroalkyl compounds in water matrices using high resolution mass spectrometry: Optimization for a laser diode thermal desorption method. Analytica Chimica Acta 881, 98-106

Munoz G, Giraudel J-L, Botta F, Lestremau F, Devier M-H, Budzinski H, Labadie P (2015b): Spatial distribution and partitioning behavior of selected poly- and perfluoroalkyl substances in freshwater ecosystems: A French nationwide survey. Science of the Total Environment 517, 48-56

Muresan, B.; Lorgeoux, C.; Gaspéri J.; Moilleron, R., Fate and spatial variations of polybrominated diphenyl ethers in the deposition within a heavily urbanized area: case of Paris (France), Water Sci Technol, 2010, 62, (4), 822-828Nam JJ, Gustafsson O, Kurt-Karakus P, Breivik K, Steinnes E, Jones KC (2008): Relationships between organic matter, black carbon and persistent organic pollutants in European background soils: Implications for sources and environmental fate. Environmental Pollution 156, 809-817

Phuong NN, Zalouk-Vergnoux A, Poirier L, Kamari A, Chatel A, Mouneyrac C, Lagarde F (2016): Is there any consistency between the microplastics found in the field and those used in laboratory experiments? Environmental pollution (Barking, Essex : 1987) 211, $111-23$

Priadi C, Ayrault S, Pacini S, Bonté P (2011): Urbanization impact on metals mobility in riverine suspended sediment: Role of metal oxides. International Journal of Environmental Science and Technology 8, 1-18 
Rasmussen PE, Subramanian KS, Jessiman BJ (2001): A multi-element profile of housedust in relation to exterior dust and soils in the city of Ottawa, Canada. Science of the Total Environment 267, 125-140

Rodrigues S, Pereira ME, Duarte AC, Ajmone-Marsan F, Davidson CM, Grcman H, Hossack I, Hursthouse AS, Ljung K, Martini C, Otabbong E, Reinoso R, Ruiz-Cortes E, Urquhart GJ, Vrscaj B (2006): Mercury in urban soils: A comparison of local spatial variability in six European cities. Science of the Total Environment 368, 926-936

Rutter AP, Schauer JJ, Shafer MM, Creswell JE, Olson MR, Robinson M, Collins RM, Parman AM, Katzman TL, Mallek JL (2011): Dry deposition of gaseous elemental mercury to plants and soils using mercury stable isotopes in a controlled environment. Atmospheric Environment 45, 848-855

Sanchez-Brunete C, Miguel E, Tadeo JL (2009): Determination of tetrabromobisphenol-A, tetrachlorobisphenol-A and bisphenol-A in soil by ultrasonic assisted extraction and gas chromatography-mass spectrometry. Journal of Chromatography A 1216, 54975503

Soclo HH, Garrigues P, Ewald M (2000): Origin of polycyclic aromatic hydrocarbons (PAHs) in coastal marine sediments: Case studies in Cotonou (Benin) and Aquitaine (France) areas. Marine Pollution Bulletin 40, 387-396

Sternbeck J, Brorström-Lundén E, Remberger M, Kaj L, Palm A, Junedahl E, Cato I (2003): WFD Priority substances in sediments from Stockholm and the Svealand coastal region. IVL B1538

Strynar MJ, Lindstrom AB, Nakayama SF, Egeghy PP, Helfant LJ (2012): Pilot scale application of a method for the analysis of perfluorinated compounds in surface soils. Chemosphere 86, 252-257

Sussarellu R, Suquet M, Thomas Y, Lambert C, Fabioux C, Pernet MEJ, Le Goic N, Quillien V, Mingant C, Epelboin Y, Corporeau C, Guyomarch J, Robbens J, Paul-Pont I, Soudant P, Huvet A (2016): Oyster reproduction is affected by exposure to polystyrene microplastics. Proc. Natl. Acad. Sci. U. S. A. 113, 2430-2435

Teil M-J, Moreau-Guigon E, Blanchard M, Alliot F, Gaspéri J, Cladière M, Mandin C, Moukhtar S, Chevreuil M (2016): Endocrine disrupting compounds in gaseous and particulate outdoor air phases according to environmental factors. Chemosphere 146, 94-104

Thévenot DR, Moilleron R, Lestel L, Gromaire M-C, Rocher V, Cambier P, Bonté P, Colin JL, de Ponteves C, Meybeck M (2007): Critical budget of metal sources and pathways in the Seine River basin (1994-2003) for $\mathrm{Cd}, \mathrm{Cr}, \mathrm{Cu}, \mathrm{Hg}, \mathrm{Ni}, \mathrm{Pb}$ and $\mathrm{Zn}$. Science of The Total Environment, Human activity and material fluxes in a regional river basin: the Seine River watershed - Seine Special Issue 375, 180-203

Thorenz, U.R., Bandowe, B.A.M., Sobocka, J., Wilcke, W. (2010). Method optimization to measure polybrominated diphenyl ether (PBDE) concentrations in soils of Bratislava, Slovakia. Environ. Pollut. 158, 2208-2217. doi:10.1016/j.envpol.2010.02.021 
A Thorpe, A and RM Harrison (2008). Sources and properties of non-exhaust particulate matter from road traffic: a review. Science of the total environment, 2008, 400, 270282.

Tlili K, Labadie P, Alliot F, Bourges C, Desportes A, Chevreuil M (2012): Polybrominated Diphenyl Ether Dynamics in Ambient Air and Atmospheric Bulk/Wet Deposition in Downtown Paris (France). Water Air and Soil Pollution 223, 1543-1553

Tran B, Teil MJ, Blanchard M, Alliot F, Chevreuil M (2015): Fate of phthalates and BPA in agricultural and non-agricultural soils of the Paris area (France). Environmental Science and Pollution Research 22, 11118-11126

Vazquez de la Cueva A, Marchant BP, Ramon Quintana J, de Santiago A, Lopez Lafuente A, Webster R (2014): Spatial variation of trace elements in the peri-urban soil of Madrid. J. Soils Sediments 14, 78-88

Vikelsoe J, Thomsen M, Carlsen L (2002): Phthalates and nonylphenols in profiles of differently dressed soils. Science of the Total Environment 296, 105-116

Villanneau EJ, Saby NPA, Marchant BP, Jolivet CC, Boulonne L, Caria G, Barriuso E, Bispo A, Briand O, Arrouays D (2011): Which persistent organic pollutants can we map in soil using a large spacing systematic soil monitoring design? A case study in Northern France. Science of the Total Environment 409, 3719-3731

Wang Q, Liu M, Yu Y, Du F, Wang X (2014): Black carbon in soils from different land use areas of Shanghai, China: Level, sources and relationship with polycyclic aromatic hydrocarbons. Applied Geochemistry 47, 36-43

Washington JW, Henderson WM, Ellington JJ, Jenkins TM, Evans JJ (2008): Analysis of perfluorinated carboxylic acids in soils II: Optimization of chromatography and extraction. Journal of Chromatography A 1181, 21-32

Yunker MB, Backus SM, Graf Pannatier E, Jeffries DS, Macdonald RW (2002a): Sources and significance of alkane and PAH hydrocarbons in Canadian arctic rivers. Estuarine Coastal and Shelf Science 55, 1-31

Yunker MB, Macdonald RW, Vingarzan R, Mitchell RH, Goyette D, Sylvestre S (2002b): PAHs in the Fraser River basin: a critical appraisal of PAH ratios as indicators of PAH source and composition. Organic Geochemistry 33, 489-515

Zareitalabad P, Siemens J, Hamer M, Amelung W (2013): Perfluorooctanoic acid (PFOA) and perfluorooctanesulfonic acid (PFOS) in surface waters, sediments, soils and wastewater - A review on concentrations and distribution coefficients. Chemosphere $91,725-732$

Zeng F, Cui K, Xie Z, Wu L, Luo D, Chen L, Lin Y, Liu M, Sun G (2009): Distribution of phthalate esters in urban soils of subtropical city, Guangzhou, China. Journal of Hazardous Materials 164, 1171-1178

Zou M-Y, Ran Y, Gong J, Maw B-X, Zeng EY (2007): Polybrominated diphenyl ethers in watershed soils of the Pearl River Delta, China: Occurrence, inventory, and fate. Environmental Science \& Technology 41, 8262-8267 



\section{Figure caption}

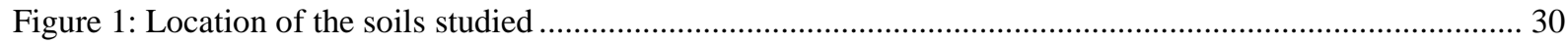

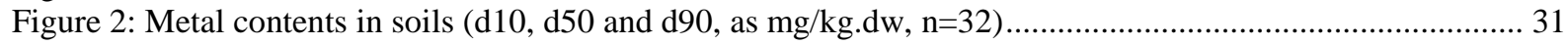

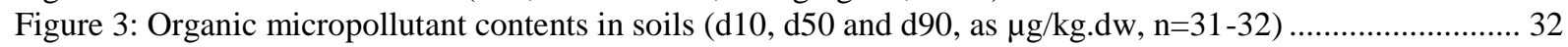

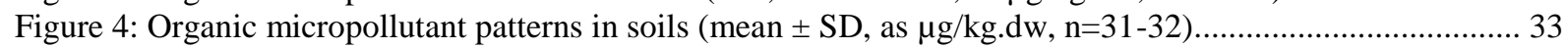




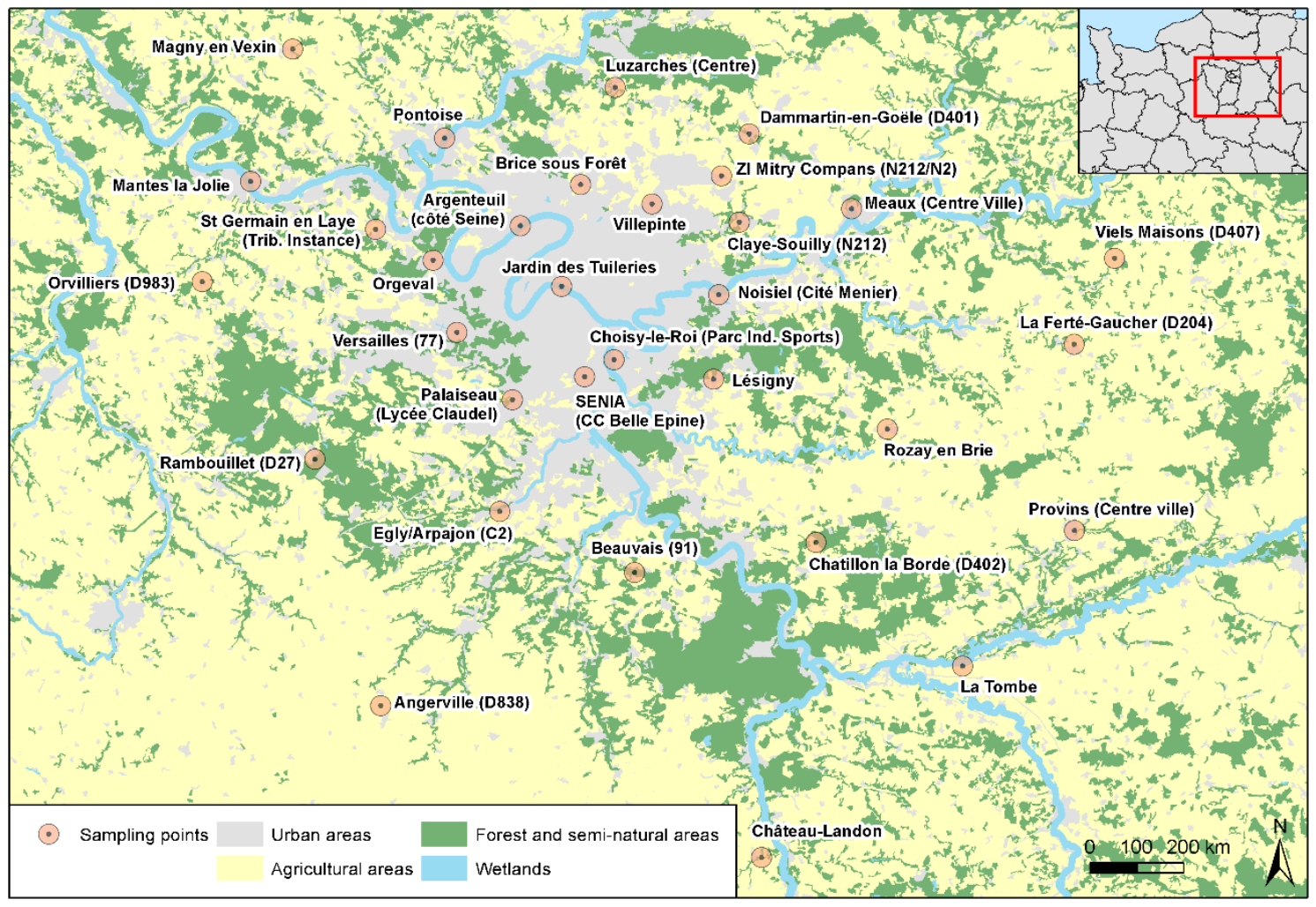

Figure 1: Location of the soils studied 


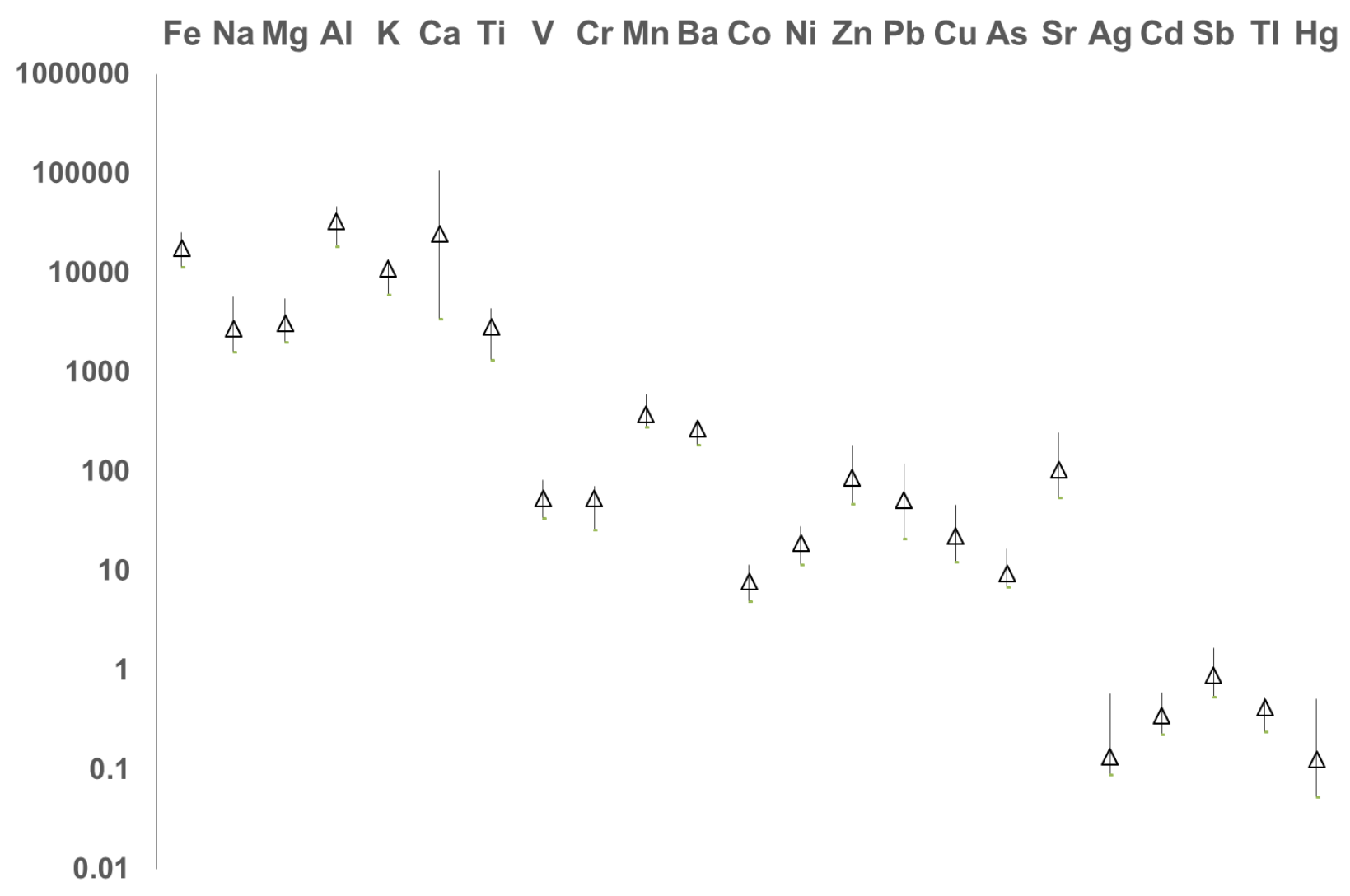

Figure 2: Metal contents in soils $(\mathrm{d10}, \mathrm{d50}$ and d90, as mg/kg.dw, $\mathrm{n}=32)$ 


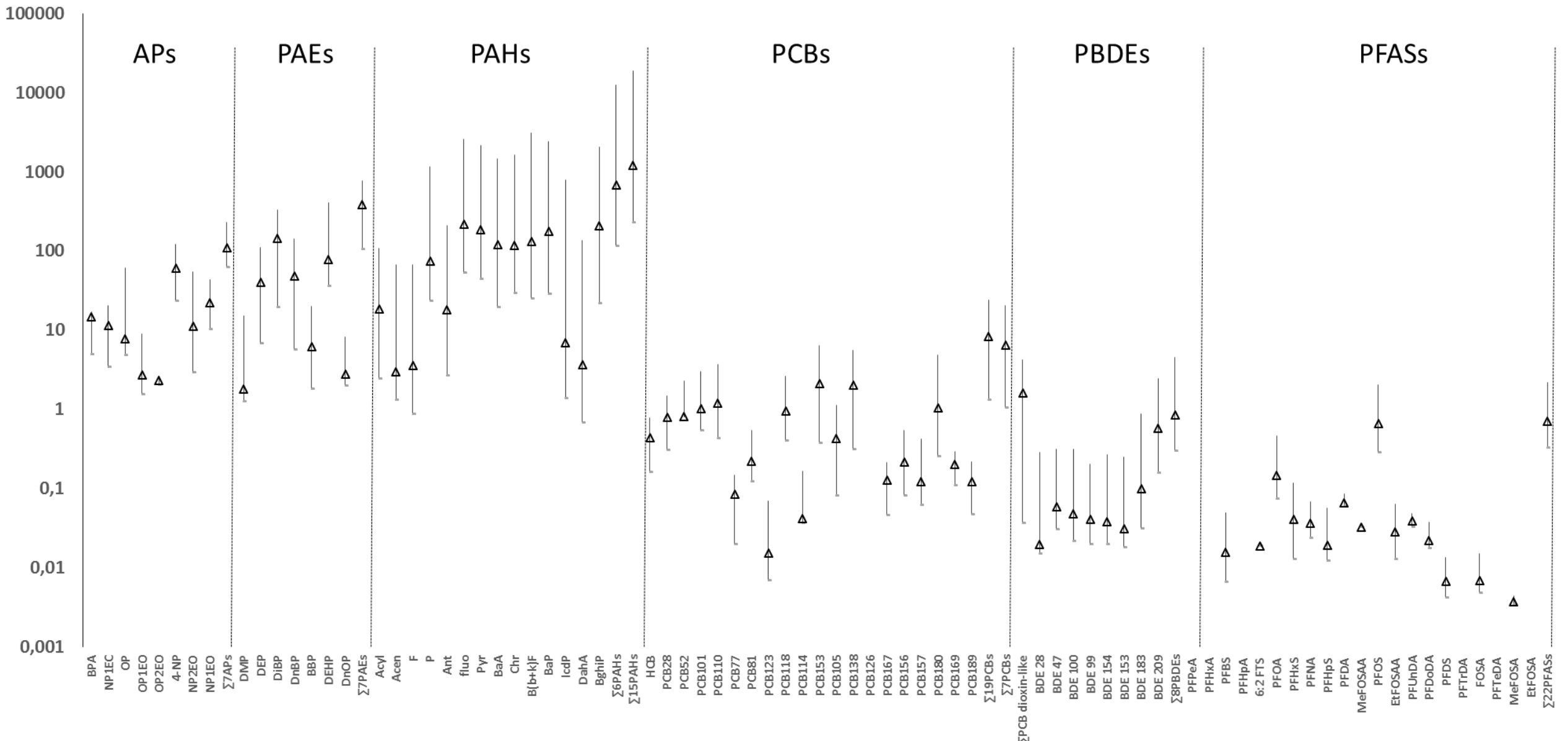



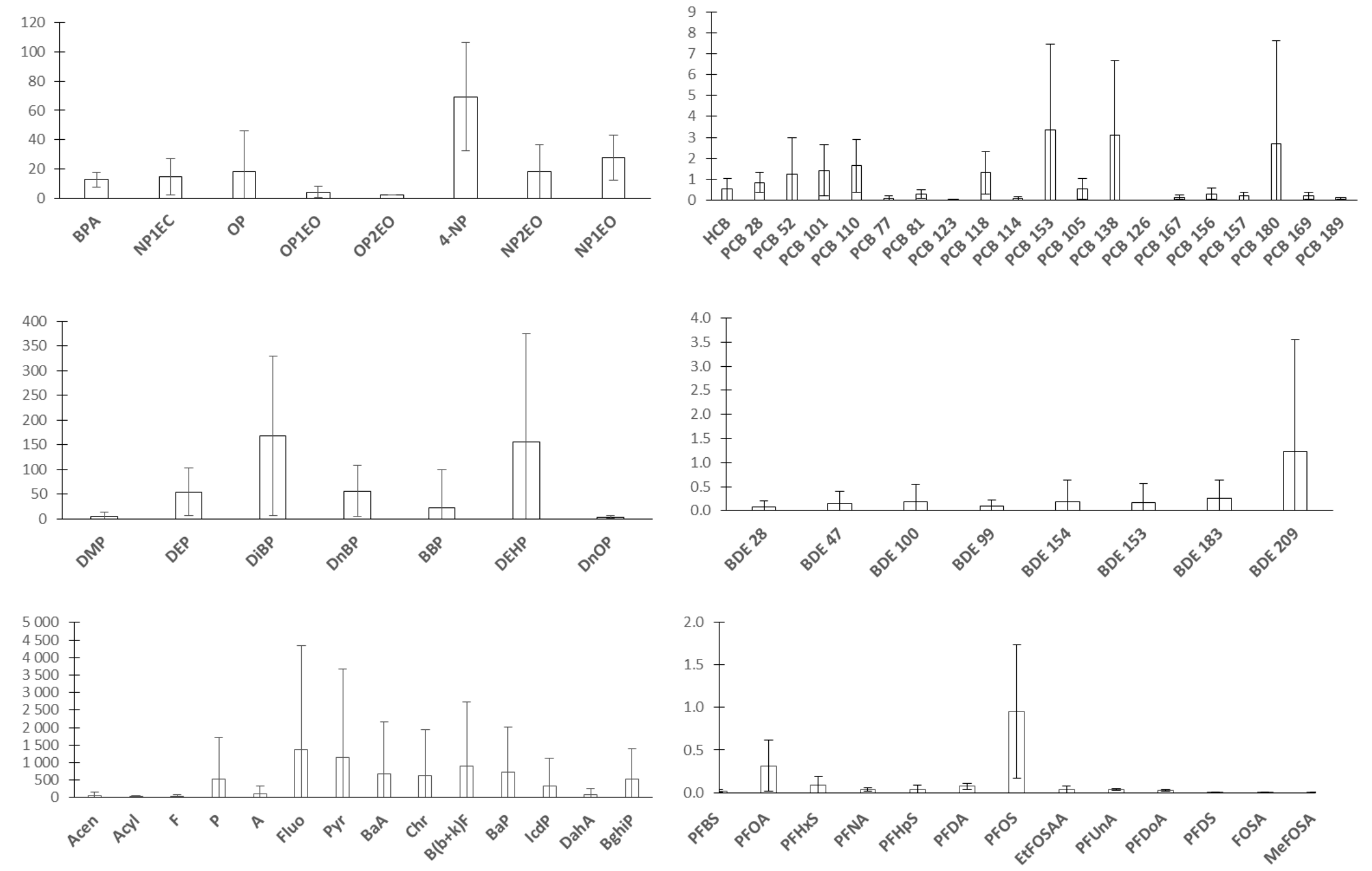

Figure 4: Organic micropollutant patterns in soils (mean $\pm \mathrm{SD}$, as $\mu \mathrm{g} / \mathrm{kg.dw}, \mathrm{n}=31-32$ ) 


\section{Table caption}

2 Table 1: Pollutants analyzed in soils ……………................................................................................... 35

3 Table 2: Metal contents (mean \pm SD) in soil in this study and in literature (contents as $\mathrm{mg} / \mathrm{kg} . \mathrm{dw}$ ) ................... 36

4 Table 3: Organic micropollutant contents in soil in this study and in literature (contents as $\mu \mathrm{g} / \mathrm{kg} . \mathrm{dw}$ ) ............. 37

$5 \quad$ Table 4: Stocks in 10-cm soil layer $v s$. atmospheric fluxes............................................................................ 38 
Table 1: Pollutants analyzed in soils

\begin{tabular}{|c|c|}
\hline Groups & Individual compounds and abbreviation \\
\hline $\begin{array}{l}\text { Metals and major elements } \\
23 \text { compounds }\end{array}$ & $\begin{array}{l}\text { sodium }(\mathrm{Na}) \text {, magnesium }(\mathrm{Mg}) \text {, aluminum }(\mathrm{Al}) \text {, potassium }(\mathrm{K}) \text {, } \\
\text { calcium }(\mathrm{Ca}) \text {, titan }(\mathrm{Ti}) \text {, vanadium }(\mathrm{V}) \text {, chrome }(\mathrm{Cr}) \text {, manganese } \\
(\mathrm{Mn}) \text {, iron }(\mathrm{Fe}) \text {, cobalt }(\mathrm{Co}) \text {, nickel }(\mathrm{Ni}) \text {, zinc }(\mathrm{Zn}) \text {, copper }(\mathrm{Cu}) \text {, } \\
\text { arsenic }(\mathrm{As}) \text {, strontium }(\mathrm{Sr}) \text {, silver }(\mathrm{Ag}) \text {, cadmium }(\mathrm{Cd}) \text {, } \\
\text { antimony }(\mathrm{Sb}) \text {, barium }(\mathrm{Ba}) \text {, thallium }(\mathrm{Tl}) \text {, lead }(\mathrm{Pb}) \text {, mercury } \\
(\mathrm{Hg})\end{array}$ \\
\hline $\begin{array}{l}\text { PAHs } \\
15 \text { compounds }\end{array}$ & $\begin{array}{l}\text { acenaphthylene (Acy), acenaphthene (Acen), Fluorene (F), } \\
\text { phenanthrene }(\mathrm{P}) \text {, anthracene }(\mathrm{A}) \text {, fluoranthene (Fluo), pyrene } \\
(\mathrm{Pyr}), \quad \text { benzo(a)anthracene }(\mathrm{BaA}), \quad \text { chrysene }(\mathrm{Chr}), \\
\text { benzo(b)fluoranthene (BbF), benzo(k)fluoranthene }(\mathrm{BkF}), \\
\text { benzo(a)pyrene (BaP), indeno(cd)pyrene }(\mathrm{IcdP}), \\
\text { dibenzo(ah)anthracene (DahA), benzo(ghi)perylene (BghiP) }\end{array}$ \\
\hline $\begin{array}{l}\text { PCBs } \\
19 \text { congeners }\end{array}$ & $\begin{array}{l}\text { PCB 28, РCB 52, РCB 77, РCB 81, РCB 101, РCB 110, РCB } \\
105, \text { PCB 118, РCB 153, РCB 114, РCB 138, РCB 123, РCB } \\
126, \text { PCB 180, РCB 156, РCB 157, РCB 167, РCB 169, РCB } \\
189\end{array}$ \\
\hline $\begin{array}{l}\text { PAEs } \\
7 \text { compounds }\end{array}$ & $\begin{array}{l}\text { di-methyl phthalate (DMP), di-ethyl phthalate (DEP), di-iso- } \\
\text { butyl phthalate (DiBP), di-n-butyl phthalate (DnBP), butyl- } \\
\text { benzyl phthalate (BBP), di-ethyl-hexyl phthalate (DEHP), di-n- } \\
\text { octyl phthalate (DnOP) }\end{array}$ \\
\hline $\begin{array}{l}\text { PBDEs } \\
8 \text { compounds }\end{array}$ & $\begin{array}{l}\text { BDE 28, BDE } 47, \text { BDE } 99, \text { BDE } 100, \text { BDE } 153, \text { BDE } 154, \\
\text { BDE } 183, \text { BDE } 209\end{array}$ \\
\hline $\begin{array}{l}\text { APs } \\
7 \text { compounds }\end{array}$ & $\begin{array}{l}\text { nonylphenols (NP), nonylphenol monoethoxylate (NP1EO), } \\
\text { nonylphenol diethoxylate (NP2EO), octylphenol (OP), } \\
\text { octylphenol monoethoxylate (OP1EO), octylphenol diethoxylate } \\
\text { (OP2EO), nonylphenoxy acetic acid (NP1EC) }\end{array}$ \\
\hline $\begin{array}{l}\text { PFASs } \\
22 \text { compounds }\end{array}$ & $\begin{array}{l}\text { perfluorobutanoïc acid (PFBA), perfluoropentanoic acid } \\
\text { (PFPeA), perfluorohexanoic acid (PFHxA), perfluorobutane } \\
\text { sulfonic acid (PFB)S, perfluoroheptanoic acid (PFHpA), } \\
\text { perfluoroheptanoic acid, 6:2 fluorotelomere sulfonate (6:2 FTS), } \\
\text { perfluorooctanoc acid (PFOA), perfluorohexane sulfonic acid } \\
\text { (PFHxS), perfluoronoanoic acid (PFNA), perfluoroheptane } \\
\text { sulfonic acid (PFHpS), perfluorodecanoique acid (PFDA), N- } \\
\text { Methyl perfluorooctane sulfonamidoacetic acid (MeFOSAA), } \\
\text { perfluorooctane sulfonic acid (PFOS), N-Ethyl perfluorooctane } \\
\text { sulfonamidoacetic acid (EtFOSAA), perfluoroundecanoic acid } \\
\text { (PFUnDA), perfluorododecanoic acid (PFDoDA), } \\
\text { perfluorodecane sulfonic acid (PFDS), perfluorotridecanoïc acid } \\
\text { (PFTrDA), perfluorooctanesulfonamide } \\
\text { perfluorotetradecanoic acid (FOSA), } \\
\text { perfluorooctane sulfonamide } \quad \text { (MeFOSA), } \\
\text { perfluorooctane sulfonamide (EtFOSA) }\end{array}$ \\
\hline $\begin{array}{l}\text { Others } \\
4 \text { compounds }\end{array}$ & $\begin{array}{l}\text { bisphenol A (BPA) } \\
\text { tetrabromobisphenol A (TBBPA), hexachlorobenzene (HCB), } \\
\text { pentachlorobenzene (PeCB) }\end{array}$ \\
\hline
\end{tabular}


Table 2: Metal contents (mean $\pm \mathrm{SD}$ ) in soil in this study and in literature (contents as $\mathrm{mg} / \mathrm{kg.dw}$ )

\begin{tabular}{|c|c|c|c|c|c|c|c|c|c|c|}
\hline & This study & $\begin{array}{l}\text { (Marcheselli } \\
\text { et al. 2010) }\end{array}$ & $\begin{array}{l}\text { (Marcheselli } \\
\text { et al. 2010) }\end{array}$ & $\begin{array}{c}\text { (Ajmone-Marsan \& } \\
\text { Biasioli 2010) }\end{array}$ & $\begin{array}{c}\text { (Vazquez de la } \\
\text { Cueva et al. } \\
\text { 2014) }\end{array}$ & $\begin{array}{c}\text { (Bermudez et } \\
\text { al. 2012) }\end{array}$ & $\begin{array}{l}\text { (Rasmussen et al. } \\
\text { 2001) }\end{array}$ & $\begin{array}{l}\text { (Hernandez-Quiroz } \\
\text { et al. 2012) }\end{array}$ & $\begin{array}{l}\text { (Imperato } \\
\text { et al. 2003) }\end{array}$ & $\begin{array}{l}\text { (Rodrigues } \\
\text { et al. 2006) }\end{array}$ \\
\hline Year & 2010 & 2010 & 2010 & 2006 & 2014 & 2012 & 2001 & 2012 & 1999 & 2006 \\
\hline Type & Mixed & Urban & Suburban & Urban & Suburban & Mixed & Urban & Urban & Urban & Urban \\
\hline As & $10.8 \pm 6.6$ & & & & & & 2.8 & & & \\
\hline $\mathrm{Cd}$ & $0.4 \pm 0.2$ & $0.43 \pm 0.02$ & $0.45 \pm 0.10$ & & $0.11 \pm 0.08$ & & 0.27 & & & \\
\hline $\mathrm{Co}$ & $9.6 \pm 11.3$ & & & & & & 8.05 & & & \\
\hline $\mathrm{Cr}$ & $50.9 \pm 20.5$ & $19.5 \pm 1.8$ & $12.2 \pm 1.4$ & $157 \pm 132$ & & & 43.4 & $48.23 \pm 11.44$ & $11 \pm 9$ & \\
\hline $\mathrm{Cu}$ & $28.0 \pm 22.6$ & $23.8 \pm 1.3$ & $22.3 \pm 1.8$ & $76 \pm 48$ & $9.50 \pm 21.33$ & $6.93 \pm 0.53$ & 12.1 & $30.31 \pm 17.64$ & $74 \pm 56$ & \\
\hline $\mathrm{Fe}$ & $\begin{array}{c}19,927 \pm \\
12,149\end{array}$ & & & & & & 20,750 & & & \\
\hline $\mathrm{Mn}$ & $473.5 \pm 445.2$ & $442 \pm 20$ & $519 \pm 22$ & & & $365 \pm 15$ & 531.6 & & & \\
\hline $\mathrm{Ni}$ & $19.2 \pm 7.6$ & $9.77 \pm 0.67$ & $7.88 \pm 0.63$ & $175 \pm 118$ & & $7.09 \pm 0.32$ & 15.8 & $31.92 \pm 18.15$ & & \\
\hline $\mathrm{Pb}$ & $210.4 \pm 799.3$ & $61.7 \pm 3.6$ & $62.1 \pm 3.5$ & $117 \pm 121$ & $17.00 \pm 98.73$ & $9.40 \pm 0.35$ & 33.78 & $29.81 \pm 11.08$ & $262 \pm 337$ & \\
\hline $\mathrm{Sb}$ & $1.8 \pm 3.5$ & & & & & & 0.22 & & & \\
\hline $\mathrm{V}$ & $54.3 \pm 21.2$ & & & & & & 45.7 & $161.65 \pm 126.81$ & & \\
\hline $\mathrm{Zn}$ & $102.8 \pm 60.0$ & $205 \pm 14$ & $207 \pm 15$ & $149 \pm 97$ & $40.00 \pm 22.04$ & & 100.2 & $125.31 \pm 59.97$ & $251 \pm 253$ & \\
\hline $\mathrm{Hg}$ & $0.40 \pm 0.67$ & & & & & & & & & $0.015-6.3$ \\
\hline
\end{tabular}


Table 3: Organic micropollutant contents in soil in this study and in literature (contents as $\mu \mathrm{g} / \mathrm{kg.dw}$ )

\begin{tabular}{|c|c|c|c|}
\hline Family & Type of soils & Levels & References \\
\hline \multirow[t]{2}{*}{ BPA } & Mixed (France) & $B P A(4.8-17.2)$ & This study ${ }^{l}$ \\
\hline & Agricultural soils & BPA $(90-110)$ & (Sanchez-Brunete et al. 2009) \\
\hline \multirow[t]{4}{*}{ APs } & Soils (France) & $N P(23-123)$ & This study \\
\hline & Urban soils (Sweden) & $\mathrm{NP}(50-9,000)$ & (Sternbeck et al. 2003) \\
\hline & Agricultural soils (Spain) & NP (140-500) & (Andreu et al. 2007) \\
\hline & Mixed & NP $(10-1,620)$ & (Bergé et al. 2012) \\
\hline \multirow[t]{8}{*}{ PAEs } & Mixed (France) & $D E H P(35-411)$ & This study \\
\hline & Amended soils (Denmark) & DEHP (30-40) & (Vikelsoe et al. 2002) \\
\hline & Mixed & DEHP (20-264,000) & (Berge et al. 2013) \\
\hline & Urban soils (China) & DEHP $(1,410-264,000)$ & (Zeng et al. 2009) \\
\hline & Sub-urban soils (China) & DEHP $(1,400-97,200)$ & (Zeng et al. 2009) \\
\hline & Park soils (China) & DEHP $(890-1,540,000)$ & (Zeng et al. 2009) \\
\hline & Urban soils (China) & $\operatorname{DiBP}(1,630)$ & (Zeng et al. 2009) \\
\hline & Urban soils (China) & $\operatorname{DnBP}(1,800)$ & (Zeng et al. 2009) \\
\hline \multirow[t]{8}{*}{ PAHs } & Mixed (France) & $\Sigma 15(228-18,940)$ & This study \\
\hline & Mixed (France) & Fluo $(52-2,561)$ & This study \\
\hline & Soils (France) & $\Sigma 16(80-400)$ & (Villanneau et al. 2011) \\
\hline & Soils (France) & Fluo $(<10-5,300)$ & (Villanneau et al. 2011) \\
\hline & Soils (France) & $\Sigma 14(450-5,650)$ & (Motelay-Massei et al. 2004) \\
\hline & Mixed (France) & $\Sigma 13(60-5,305)$ & (Gateuille et al. 2014a) \\
\hline & Soils (UK) & $\Sigma 14(42-11,200)$ & (Nam et al. 2008) \\
\hline & Soils (Norway) & $\Sigma 14(9-1,100)$ & (Nam et al. 2008) \\
\hline \multirow[t]{4}{*}{ PCBs } & Mixed (France) & $\Sigma 19(1.3-24.3)$ & This study \\
\hline & Soils (France) & $\Sigma 20(0.5-17)$ & (Villanneau et al. 2011) \\
\hline & Soils (France) & $\Sigma 19(0.1-150)$ & (Motelay-Massei et al. 2004) \\
\hline & Mixed & $\Sigma 29(0.03-96)$ & (Meijer et al. 2003) \\
\hline \multirow[t]{3}{*}{ PBDEs } & Mixed (France) & BDE $209(0.2-2.4)$ & This study \\
\hline & Mixed & BDE 209 (0.6-4) & (Hassanin et al. 2004) \\
\hline & Mixed (China) & BDE 209 (9-102) & (Zou et al. 2007) \\
\hline \multirow[t]{10}{*}{ PFAS } & Mixed (France) & PFOA (0.07-0.46) & This study \\
\hline & Mixed (France) & $\operatorname{PFOS}(0.28-2.05)$ & This study \\
\hline & Mixed (6 countries) & PFOA $(0.12)$ & (Strynar et al. 2012) \\
\hline & Mixed (6 countries) & PFOS (0.472) & (Strynar et al. 2012) \\
\hline & Mixed (6 countries) & Individual PFASs (0.5-79) & (Strynar et al. 2012) \\
\hline & Soils (US) & $\sum 5$ carboxylates $(0.5-1.5)$ & (Washington et al. 2008) \\
\hline & Mixed & PFOA $(0.3-47.5)$ & (Zareitalabad et al. 2013) \\
\hline & Mixed & PFOS $(0.5-483)$ & (Zareitalabad et al. 2013) \\
\hline & Soils (China) & PFOA (3.28-47.5) & (Li et al. 2010) \\
\hline & Soils (China) & PFOS (8.58-10.4) & (Li et al. 2010) \\
\hline
\end{tabular}


Table 4: Stocks in 10-cm soil layer vs. atmospheric fluxes

\begin{tabular}{|c|c|c|c|c|c|c|}
\hline & $\begin{array}{c}\text { Stocks* } \\
\left(\mu \mathrm{g} / \mathbf{m}^{2} \text { or }\right. \\
\left.\mathbf{m g} / \mathbf{m}^{2}\right)\end{array}$ & $\begin{array}{c}\text { Atm fluxes** } \\
\left(\mu g / \mathbf{m}^{2} \text { or }\right. \\
\left.\mathrm{mg} / \mathrm{m}^{2} / \text { year }\right) \\
\text { Min }\end{array}$ & $\begin{array}{c}\text { Atm fluxes } * * \\
\left(\mu g / m^{2} \text { or }\right. \\
\text { mg/m²/year }) \\
\text { Max }\end{array}$ & References & $\begin{array}{c}\text { Ratio } \\
\text { Stocks/Flux } \\
\text { Min }\end{array}$ & $\begin{array}{c}\text { Ratio } \\
\text { Stocks/Flux } \\
\text { Max }\end{array}$ \\
\hline BPA & 2,950 & 11.00 & 56.00 & (Cladière 2012) & 268 & 53 \\
\hline$\sum 7 \mathrm{APs}$ & 22,077 & 50.00 & 117.00 & (Cladière 2012) & 442 & 189 \\
\hline DEHP & 15,641 & 185.00 & 393.00 & (Dargnat 2008) & 85 & 40 \\
\hline$\sum 7$ PAEs & 76,781 & 326.00 & 691.00 & (Dargnat 2008) & 236 & 11 \\
\hline$\sum 6 \mathrm{PAHs}$ & 135,150 & 31.00 & 104.00 & $\begin{array}{l}\text { (Motelay-Massei } \\
\text { et al. 2007) }\end{array}$ & 4,359 & 1,299 \\
\hline$\sum 15$ PAHs & 239,500 & 66.00 & 227.00 & $\begin{array}{l}\text { (Motelay-Massei } \\
\text { et al. 2007) }\end{array}$ & 3,628 & 1,055 \\
\hline$\sum 7 \mathrm{PCBs}$ & 1,676 & 3.60 & 35.00 & $\begin{array}{c}\text { (Blanchard et al. } \\
\text { 2006) }\end{array}$ & 99 & 13 \\
\hline$\sum 19 \mathrm{PCBs}$ & 1,301 & 16.90 & 125.00 & $\begin{array}{c}\text { (Blanchard et al. } \\
\text { 2006) }\end{array}$ & 361 & 37 \\
\hline$\sum 8 \mathrm{PBDEs}$ & 170 & 2.50 & 43.00 & (Tlili et al. 2012) & 68 & 4 \\
\hline$\sum 8 \mathrm{PBDEs}$ & 337 & 18.00 & 47.45 & $\begin{array}{l}\text { Muresan et al., } \\
2010)\end{array}$ & 19 & 7 \\
\hline$\sum 22$ PFASs & 141 & 4.00 & 5.00 & $\begin{array}{l}\text { (Labadie, personal } \\
\text { communication) }\end{array}$ & 35 & 28 \\
\hline$\sum 22 \mathrm{PFASs}$ & 282 & 11.00 & 22.00 & (Kwok et al. 2010) & 25 & 12 \\
\hline $\mathrm{Zn}$ & 17,100 & 20.00 & 50.00 & (Azimi et al. 2005) & 854 & 341 \\
\hline $\mathrm{Cu}$ & 4,480 & 8.00 & 15.00 & (Azimi et al. 2005) & 560 & 299 \\
\hline $\mathrm{Cd}$ & 71 & 0.30 & 1.10 & (Azimi et al. 2005) & 235 & 64 \\
\hline $\mathrm{Pb}$ & 10,350 & 5.00 & 10.00 & (Azimi et al. 2005) & 2,070 & 1,035 \\
\hline $\mathrm{Hg}$ & 10 & 0.005 & 0.04 & (Allan et al. 2013) & 2,000 & 250 \\
\hline $\mathrm{Sb}$ & 180 & 0.055 & 0.055 & $\begin{array}{c}\text { (Ayrault et al. } \\
\text { 2013) }\end{array}$ & 890 & 890 \\
\hline
\end{tabular}

* Stocks in $\mu \mathrm{g} / \mathrm{m}^{2}$ for organic micropollutants and $\mathrm{mg} / \mathrm{m}^{2}$ for metals

**Atm Flux=atmospheric flux in $\mu \mathrm{g} / \mathrm{m}^{2} /$ year for organic micropollutants and $\mathrm{mg} / \mathrm{m}^{2} /$ year for metals 


\section{Supplementary material caption}

2 Supplementary - Figure S1: PAH ratios in soils - Red square refers to soil samples ......................................... 40

3 Supplementary - Figure S2: PCA on soil contamination for metals and organic micropollutants ....................... 41

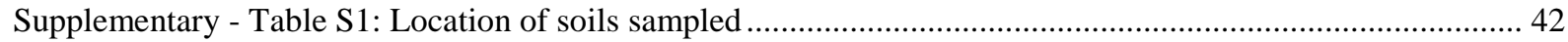

Supplementary - Table S2: Limits of quantification of pollutants monitored .................................................... 43

8 


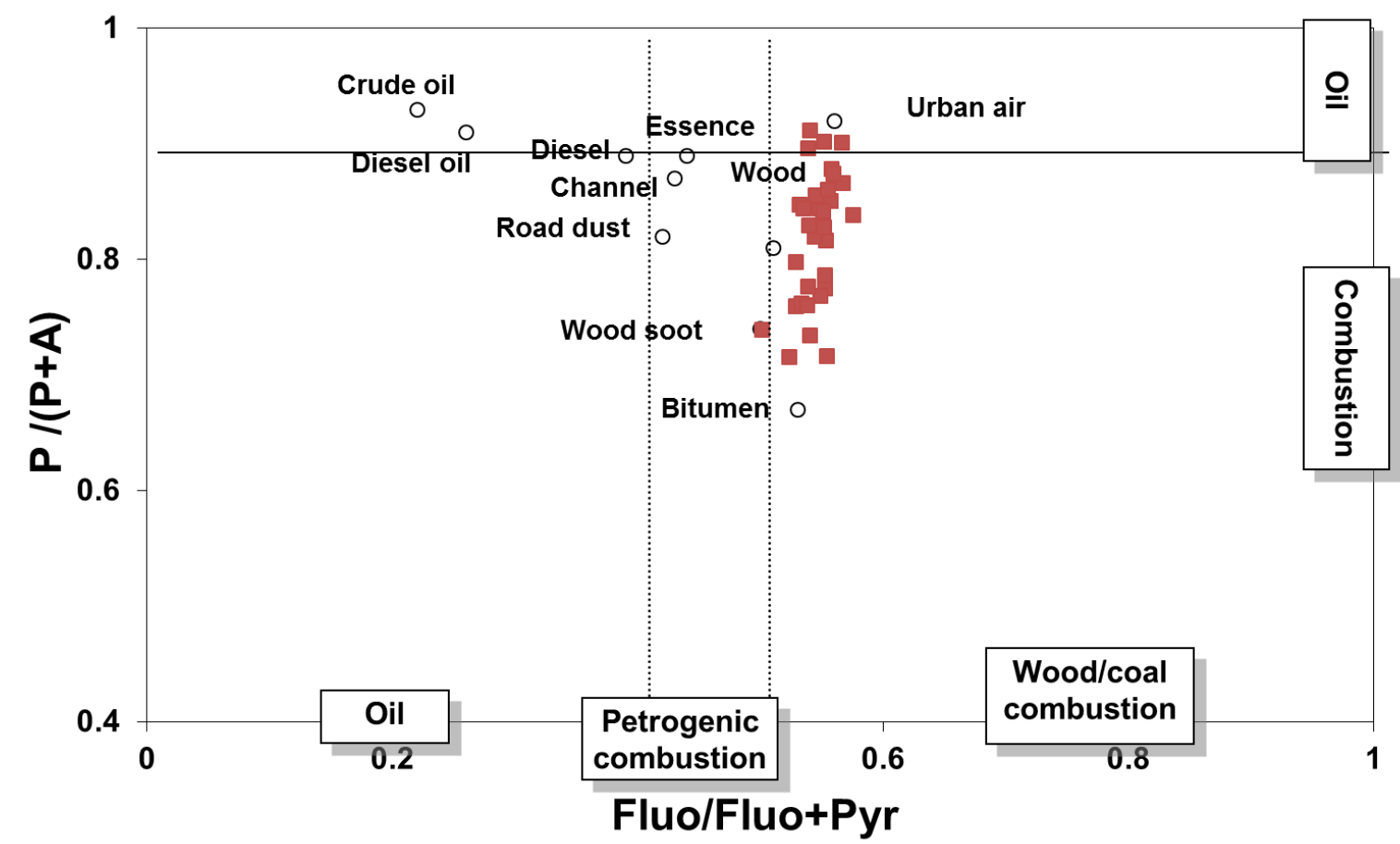
Supplementary - Figure S1: PAH ratios in soils - Red square refers to soil samples 3 
Metals

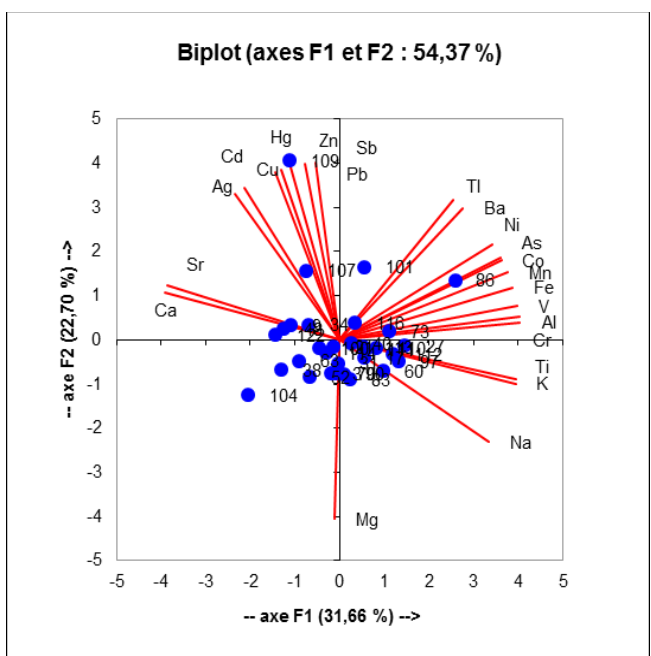

Organic micropollutants

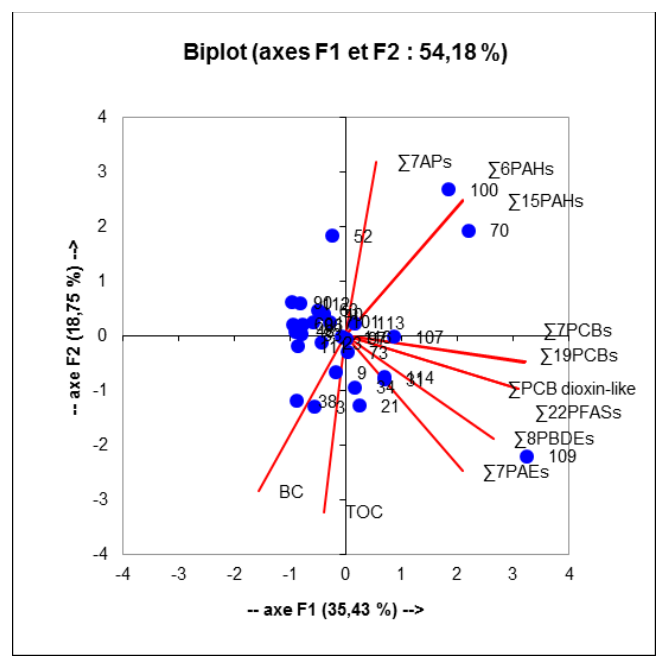

Supplementary - Figure S2: PCA on soil contamination for metals and organic micropollutants 
Supplementary - Table S1: Location of soils sampled

\begin{tabular}{|c|c|c|c|c|c|}
\hline Site & Description & $\mathrm{Nr}$ & Cat & Location & \\
\hline Beauvais & Forest & 91 & $\mathrm{~F}$ & $48^{\circ} 30^{\prime} 9.19^{\prime \prime} \mathrm{N}$ & $2^{\circ} 28^{\prime} 9.27^{\prime \prime} \mathrm{E}$ \\
\hline Rambouillet & Forest & 86 & $\mathrm{~F}$ & $48^{\circ} 38^{\prime} 28.82^{\prime \prime} \mathrm{N}$ & $1^{\circ} 51^{\prime} 39.73 " \mathrm{E}$ \\
\hline Rozay-en-Brie & Agricultural area & 17 & PA & $48^{\circ} 41^{\prime} 4.60^{\prime \prime} \mathrm{N}$ & $2^{\circ} 56^{\prime} 53.20^{\prime \prime} \mathrm{E}$ \\
\hline Chatillon-la-Borde & Agricultural area & 3 & PA & $48^{\circ} 32^{\prime} 30.54^{\prime \prime N}$ & $2^{\circ} 48^{\prime} 44.83^{\prime \prime} \mathrm{E}$ \\
\hline Magny-en-Vexin & Agricultural area & 31 & PA & $49^{\circ} 9^{\prime} 25.33 " \mathrm{~N}$ & $1^{\circ} 48^{\prime} 25.14 " \mathrm{E}$ \\
\hline Viels-Maisons & Agricultural area & 70 & PA & $48^{\circ} 53^{\prime} 56.90^{\prime \prime} \mathrm{N}$ & $3^{\circ} 22^{\prime} 51.80^{\prime \prime} \mathrm{E}$ \\
\hline La Ferté-Gaucher & Agricultural area & 73 & PA & $48^{\circ} 47^{\prime} 26.75^{\prime \prime N}$ & $3^{\circ} 18^{\prime} 11.79^{\prime \prime} \mathrm{E}$ \\
\hline Egly/Arpajon & Agricultural area & 83 & PA & $48^{\circ} 34^{\prime} 40.56^{\prime \prime} \mathrm{N}$ & $2^{\circ} 12^{\prime} 46.55^{\prime \prime} \mathrm{E}$ \\
\hline La Tombe & Agricultural area & 48 & PA & $48^{\circ} 23^{\prime} 10.26^{\prime \prime N}$ & $3^{\circ} 5^{\prime} 25.77^{\prime \prime} \mathrm{E}$ \\
\hline Chateau-Landon & Agricultural area & 52 & PA & $48^{\circ} 8 ' 40.46^{\prime \prime N}$ & $2^{\circ} 42^{\prime} 42.85^{\prime \prime} \mathrm{E}$ \\
\hline Angerville & Agricultural area & 60 & PA & $48^{\circ} 19^{\prime} 55.46^{\prime \prime} \mathrm{N}$ & $1^{\circ} 59 ' 30.35^{\prime \prime} \mathrm{E}$ \\
\hline Orvilliers & Agricultural area & 90 & PA & $48^{\circ} 51^{\prime} 44.07 " \mathrm{~N}$ & $1^{\circ} 38 ' 29.85^{\prime \prime} \mathrm{E}$ \\
\hline Provins & Urban area & 9 & Urb & $48^{\circ} 33^{\prime} 23.62^{\prime \prime} \mathrm{N}$ & $3^{\circ} 18^{\prime} 9.51^{\prime \prime E}$ \\
\hline Lésigny & Urban area & 21 & Urb & $48^{\circ} 44^{\prime} 47.69^{\prime \prime} \mathrm{N}$ & $2^{\circ} 37^{\prime} 3.23^{\prime \prime} \mathrm{E}$ \\
\hline Luzarches & Urban area & 23 & Urb & $49^{\circ} 6{ }^{\prime} 47.47 " \mathrm{~N}$ & $2^{\circ} 25^{\prime} 34.42^{\prime \prime} \mathrm{E}$ \\
\hline Pontoise & Urban area & 27 & Urb & $49^{\circ} 2 ' 49.87 " \mathrm{~N}$ & $2^{\circ} 6^{\prime} 0.26 " \mathrm{E}$ \\
\hline St Germain-en-Laye & Urban area & 40 & Urb & $48^{\circ} 53^{\prime} 36.40^{\prime \prime} \mathrm{N}$ & $2^{\circ} 4^{\prime} 52.11 " \mathrm{E}$ \\
\hline Orgeval & Urban area & 38 & Urb & $48^{\circ} 55^{\prime} 53.14^{\prime \prime N}$ & $1^{\circ} 58^{\prime} 14.74^{\prime \prime E}$ \\
\hline Dammartin-en-Goële & Urban area & 63 & Urb & $49^{\circ} 3 ' 21.13 " \mathrm{~N}$ & $2^{\circ} 41^{\prime} 0.28 " \mathrm{E}$ \\
\hline Mantes-la-Jolie & Urban area & 34 & Urb & $48^{\circ} 59^{\prime} 21.80^{\prime \prime} \mathrm{N}$ & $1^{\circ} 43^{\prime} 50.41^{\prime \prime} \mathrm{E}$ \\
\hline Palaiseau & Urban area & 97 & Urb & $48^{\circ} 43^{\prime} 8.24 " \mathrm{~N}$ & $2^{\circ} 14 ' 5.88^{\prime \prime} \mathrm{E}$ \\
\hline SENIA & Urban area & 100 & Urb & $48^{\circ} 44^{\prime} 22.51^{\prime \prime} \mathrm{N}$ & $2^{\circ} 22^{\prime} 06.72^{\prime \prime} \mathrm{E}$ \\
\hline Choisy-le-Roi & Urban area & 101 & Urb & $48^{\circ} 46^{\prime} 13.85^{\prime \prime} \mathrm{N}$ & $2^{\circ} 25^{\prime} 40.03^{\prime \prime} \mathrm{E}$ \\
\hline Versailles & Urban area & 107 & Urb & $48^{\circ} 48^{\prime} 10.56^{\prime \prime} \mathrm{N}$ & $2^{\circ} 7^{\prime} 41.73^{\prime \prime} \mathrm{E}$ \\
\hline Argenteuil & Urban area & 109 & Urb & $48^{\circ} 56^{\prime} 11.79^{\prime \prime} \mathrm{N}$ & $2^{\circ} 14^{\prime} 57.30^{\prime \prime} \mathrm{E}$ \\
\hline Villepinte & Urban area & 111 & Urb & $48^{\circ} 57^{\prime} 59.78^{\prime \prime N}$ & $2^{\circ} 29^{\prime} 54.59 " \mathrm{E}$ \\
\hline Claye-Souilly & Urban area & 113 & Urb & $48^{\circ} 56^{\prime} 40.50^{\prime \prime} \mathrm{N}$ & $2^{\circ} 39^{\prime} 54.71 " \mathrm{E}$ \\
\hline Meaux & Urban area & 114 & Urb & $48^{\circ} 57^{\prime} 42.41^{\prime \prime N}$ & $2^{\circ} 52^{\prime} 45.32^{\prime \prime} \mathrm{E}$ \\
\hline Noisiel & Urban area & 116 & Urb & $48^{\circ} 51 ' 10.90^{\prime \prime} \mathrm{N}$ & $2^{\circ} 37^{\prime} 35.64 " \mathrm{E}$ \\
\hline Jardin des Tuileries & Urban area & 122 & Urb & $48^{\circ} 51^{\prime} 44.67^{\prime \prime N}$ & $48^{\circ} 51^{\prime} 44.67^{\prime \prime} \mathrm{N}$ \\
\hline ZI Mitry-Compans & Industrial area & 112 & ZI & $49^{\circ} 00^{\prime} 10.20 " \mathrm{~N}$ & $2^{\circ} 37^{\prime} 49.29^{\prime \prime} \mathrm{E}$ \\
\hline ZI Brice-sous-Forêt & Industrial area & 110 & $\mathrm{ZI}$ & $48^{\circ} 59^{\prime} 27.19^{\prime \prime} \mathrm{N}$ & $2^{\circ} 21^{\prime} 41.02^{\prime \prime} \mathrm{E}$ \\
\hline
\end{tabular}


Supplementary - Table S2: Limits of quantification of pollutants monitored

\begin{tabular}{|c|c|c|c|c|c|}
\hline & & $\operatorname{LOQ}(\mu \mathrm{g} / \mathrm{kg})$ & & & $\operatorname{LOQ}(\mu \mathrm{g} / \mathrm{kg})$ \\
\hline $\mathrm{AP}$ & BPA & 13.5 & PBDE & BDE 28 & 0.01 \\
\hline $\mathrm{AP}$ & NP1EC & 2.0 & PBDE & BDE 47 & 0.01 \\
\hline $\mathrm{AP}$ & $\mathrm{OP}$ & 4.0 & PBDE & BDE 100 & 0.01 \\
\hline $\mathrm{AP}$ & OP1EO & 15.0 & PBDE & BDE 99 & 0.01 \\
\hline $\mathrm{AP}$ & OP2EO & 3.5 & PBDE & BDE 154 & 0.01 \\
\hline $\mathrm{AP}$ & $\mathrm{NP}$ & 7.5 & PBDE & BDE 153 & 0.01 \\
\hline $\mathrm{AP}$ & NP2EO & 7.0 & PBDE & BDE 183 & 0.01 \\
\hline $\mathrm{AP}$ & NP1EO & 5.0 & PBDE & BDE 209 & 0.06 \\
\hline PAE & DMP & 0.1 & PFAS & PFPeA & 0.01 \\
\hline PAE & DEP & 0.3 & PFAS & PFHxA & 0.08 \\
\hline PAE & DiBP & 0.07 & PFAS & PFBS & 0.01 \\
\hline PAE & DnBP & 0.06 & PFAS & PFHpA & 0.02 \\
\hline PAE & BBP & 0.1 & PFAS & 6:2 FTS & 0.04 \\
\hline PAE & DEHP & 0.6 & PFAS & PFOA & 0.02 \\
\hline PAE & DnOP & 0.5 & PFAS & PFHxS & 0.03 \\
\hline PAH & acenaphthylene & 0.31 & PFAS & PFNA & 0.05 \\
\hline PAH & acenaphthene & 0.4 & PFAS & PFHpS & 0.03 \\
\hline PAH & fluorene & 0.82 & PFAS & PFDA & 0.03 \\
\hline PAH & phenanthrene & 2.49 & PFAS & MeFOSAA & 0.04 \\
\hline PAH & anthracene & 1.7 & PFAS & PFOS & 0.02 \\
\hline PAH & fluoranthene & 0.32 & PFAS & EtFOSAA & 0.03 \\
\hline PAH & pyrene & 0.16 & PFAS & PFUnDA & 0.09 \\
\hline PAH & benzo(a)anthracene & 0.17 & PFAS & PFDoDA & 0.04 \\
\hline PAH & chrysene & 0.1 & PFAS & PFDS & 0.01 \\
\hline PAH & benzo $(b+k)$ fluoranthenes & 0.2 & PFAS & PFTrDA & 0.02 \\
\hline PAH & benzo(a)pyrene & 0.63 & PFAS & FOSA & 0.00 \\
\hline PAH & indeno(1,2,3-cd)pyrene & 0.5 & PFAS & PFTeDA & 0.04 \\
\hline PAH & dibenzo(ah)pyrene & 0.5 & PFAS & MeFOSA & 0.01 \\
\hline PAH & benzo(ghi)perylene & 1.81 & PFAS & EtFOSA & 0.01 \\
\hline PCB & $\mathrm{HCB}$ & 0.08 & РCB & PCB153 & 0.06 \\
\hline PCB & PCB28 & 0.17 & PCB & PCB105 & 0.02 \\
\hline PCB & PCB52 & 0.3 & РCB & PCB138 & 0.04 \\
\hline PCB & PCB101 & 0.07 & РCB & PCB126 & 0.49 \\
\hline PCB & PCB110 & 0.05 & PCB & PCB167 & 0.02 \\
\hline PCB & PCB77 & 0.16 & PCB & PCB156 & 0.06 \\
\hline $\mathrm{PCB}$ & PCB81 & 0.08 & PCB & PCB157 & 0.05 \\
\hline PCB & PCB123 & 0.14 & PCB & PCB180 & 0.04 \\
\hline PCB & PCB118 & 0.10 & PCB & PCB169 & 0.08 \\
\hline PCB & PCB114 & 0.02 & РCB & PCB189 & 0.04 \\
\hline
\end{tabular}

